\title{
Instagram Sebagai Medium Komunikasi Risiko Orang Tua Kepada Anak Selama Pandemi Covid-19: Studi Netnografi Komunitas Pola Asuh Virtual
}

\section{Instagram as a Medium of Communication Risks Parents to Children During Covid-19 Pandemic: Virtual Parenting Community Netnography Study}

\author{
Jihad Muamar ${ }^{*}$, Ghina Hana Imtinan
}

Universitas Pembangunan Jaya, Tangerang Selatan, (021)7455555, Kode Pos 15224, Indonesia

${ }^{*}$ E-mail korespondensi: jihadmuamar@student.upj.ac.id

Diterima: 15 Desember 2021 | Disetujui: 04 Februari 2022 | Publikasi online: 17 Februari 2022

\section{ABSTRACT}

Instagram as the third popular social media in Indonesia has a big role during the Covid-19 pandemic, namely as an effective risk communication medium, being a forum for distributing information that reaches a wide audience. This study reveals how the upload strategy is reviewed from three studies, theme as an element of grouping similar discussions, function of communication as an element of informative, educative, motivational, and the form which is an element of using features in Instagram for distributing communication. The method in this study uses the constructivism paradigm and a netnographic study approach with the parameters of uploading research analysis data was an upload related to risk communication of children's health during the Covid-19 period. Data collection was carried out through triangulation tests several times involving two types of data, primary and secondary. The results show that the risk communication strategy about children's health via Instagram by the three virtual account communities is dynamic (there is acceptance and rejection from the audience). The theme of preventive efforts, informative functions, and photo forms are important needs for the target audience, specially parents. This study shows that an effective strategy is needed to communicate risks about children's health during Covid-19 pandemic.

Kata kunci: Instagram, Netnography, Parenting, Risk Communication, Virtual Community.

\section{ABSTRAK}

Instagram sebagai media sosial populer ketiga di Indonesia memiliki peran besar di masa pandemi Covid-19, yakni sebagai medium komunikasi risiko efektif yang menyalurkan informasi yang menjangkau khalayak luas. Penelitian ini mengungkapkan bagaimana unsur strategi unggahan postingan ditinjau dari tiga kajian, yakni tema sebagai unsur pengelompokkan bahasan sejenis, fungsi komunikasi sebagai unsur layanan informatif, edukatif, motivatif, serta bentuk yang merupakan unsur penggunaan fitur Instagram sebagai media penyaluran komunikasi. Metode dalam penelitian ini menggunakan paradigma konstruktivisme, pendekatan studi netnografi dengan parameter unggahan data analisis penelitian adalah postingan terkait komunikasi risiko tentang kesehatan anak di masa Covid-19 yang diperoleh melalui unggahan ketiga akun komunitas virtual: @ayahbunda_; @parentalk.id; dan@gaia_parenting. Pengumpulan data dilakukan melalui uji triangulasi multiple times yang melibatkan dua jenis data, yakni primer (proses arsip, elisitas, dan catatan lapangan), dan sekunder (kajian artikel dan re-post terhadap postingan terkait). Hasil penelitian menunjukkan bahwa strategi komunikasi risiko tentang kesehatan anak via Instagram oleh ketiga akun komunitas virtual bersifat dinamis, artinya terdapat penerimaan dan penolakkan dari khalayak. Tema upaya preventif, fungsi informatif, dan bentuk foto menjadi kebutuhan penting bagi target khalayak, yakni para orang tua di saat masa pandemi. Kajian ini menunjukkan bahwa diperlukan strategi efektif dalam melakukan komunikasi risiko tentang kesehatan anak di masa pandemi.

Kata kunci: Instagram, Komunikasi Risiko, Netnografi, Pola Asuh Anak, Komunitas Virtual

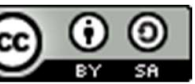




\section{PENDAHULUAN}

Pandemi virus COVID-19 hadir sebagai tantangan sendiri bagi sistem kesehatan dan kemampuan masyarakat untuk berkomunikasi secara efektif. Salah satu intervensi kesehatan yang penting dalam menghadapi situasi darurat, seperti epidemi, pandemi, krisis kemanusiaan, dan bencana alam adalah komunikasi risiko. Karena selama terjadi kondisi darurat bagi kesehatan masyarakat, komunikasi risiko yang efektif memungkinkan orang yang paling berisiko untuk memahami dan mengadopsi perilaku protektif. World Health Organization (WHO), dalam buku "Risk Communication and Community Engagement Response to (COVID-19)" menuliskan bahwa dalam kondisi darurat kesehatan masyarakat, komunikasi risiko mencakup berbagai fase kesiapan, respon, dan pemulihan dari peristiwa ancaman kesehatan masyarakat, serta secara serius dilakukan untuk mendorong pengambilan keputusan yang terinformasi, perubahan perilaku positif, dan pemeliharaan kepercayaan. Komunikasi risiko dilihat sebagai pedoman penyebaran informasi kepada publik tentang risiko terkait kejadian kesehatan, seperti wabah penyakit dan instruksi tentang cara mengubah perilaku untuk mengurangi risiko tersebut. Bentuk komunikasi risiko sebagai bagian integral tanggap darurat kesehatan masyarakat adalah pertukaran informasi, saran, dan opini antara para ahli, pejabat, tokoh masyarakat atau komunitas dengan tujuan memberikan perlindungan dari bahaya ancaman kesehatan (WHO, 2020).

Media sosial merupakan salah satu platform yang membantu orang berinteraksi dan bersosialisasi tanpa terhalang jarak ruang dan waktu. Penyediaan website dan pembuatan akun di media sosial dapat dimanfaatkan sebagai media komunikasi agar diseminasi informasi berlangsung secara cepat dan menjangkau seluruh lapisan masyarakat. Oleh karena itu, media sosial mencoba mengajak siapa saja bagi pengguna yang tertarik untuk berpartisipasi dalam memberi upaya kontribusi dan feedback secara lebih terbuka, memberi tanggapan atau komentar, membagi hal penting atau informasi dalam waktu cepat dan tak terbatas (Kaplan \& Haenlein, 2010). Berdasarkan konsep fungsi media sosial, dapat dikatakan bahwa media sosial merupakan platform atau saluran informasi yang paling tepat untuk melakukan komunikasi risiko. Berdasarkan penelitian berjudul "Risk Communication During COVID19", mengungkapkan bahwa media sosial adalah cara potensial untuk memastikan komunikasi risiko berjalan dengan tepat, karena publik sangat bergantung pada media dan hubungan sosial untuk menginformasikan tingkat persepsi risiko mereka (Abrams \& Greenhawt, 2020). Dalam penelitian lainnya berjudul "The Role of Decision-maker in Crisis Management: A qualitative Study Using Grounded Theory (COVID-19 Pandemic Crisis as A Model)" menunjukkan bahwa media sosial Instagram merupakan salah satu platform media sosial yang tepat dalam melakukan komunikasi risiko yang dinilai efektif dan murah dalam mengedukasi masyarakat untuk mencegah penyebaran virus melalui mencuci tangan secara teratur, di mana kampanye dalam Instagram ini mendapat banyak feedback positif dari followers (Dabbagh, 2020).

Berbagai penelitian terkait komunikasi risiko melalui media Instagram telah banyak dilakukan, seperti "Instagram sebagai Medium Komunikasi Risiko di Masa Pandemi COVID-19: Studi Netnografi terhadap Komunitas Online KawalCOVID19.id" yang menemukan bahwa komunikasi risiko akan efektif disampaikan melalui Instagram menggunakan konten infografis dan bersifat informatif (Damayanti, 2020). Dalam penelitian yang dilakukan oleh Damayanti, fokus kajian dilakukan mengenai konten komunikasi risiko secara umum yang menyasar publik secara umum juga. Berbeda halnya dengan kajian yang dilakukan dalam jurnal ini lebih spesifik membahas konten terkait komunikasi risiko tentang kesehatan anak dengan target khalayak adalah para orang tua. Penelitian selanjutnya terkait komunikasi risiko melalui media Instagram adalah "Analisis Konten Komunikasi Risiko Di Akun Instagram Gubernur Provinsi Sumatera Utara Selama Pandemi Covid-19" yang menemukan bahwa target pesan cenderung mengarah pada memberikan informasi mengenai Covid-19 $(38,5 \%)$, target sasaran cenderung mengarah pada masyarakat umum sebanyak $(74 \%)$, isi pesan cenderung mengarah pada aktifitas pencegahan $(37,5 \%)$, referensi pesan cenderung mengarah pada tanpa referensi $(85,6 \%)$ dan intonasi pesan cenderung mengarah pada pesan positif $(97,1 \%)$ (Hasanah \& Suswardany, 2021). Penelitian analisis konten yang dilakukan oleh Hasanah ini menjadi dasar yang digunakan penulis untuk melihat bagaimana tema, bentuk, dan fungsi pesan yang dikemas dalam menyampaikan komunikasi risiko di masa pandemi. Perbedaannya adalah analisis konten yang dikaji oleh penelitian Hasanah berfokus pada unggahan di akun Instagram Gubernur Provinsi Sumatra Utara, yang tujuannya menyampaikan informasi kepada masyarakat umum, khususnya masyarakat di Provinsi Sumatera Utara, sedangkan dalam kajian penelitian ini akan berfokus mengenai konten komunikasi risiko yang membahas tentang anak dengan target sasaran khalayak khusus para orang tua. 
Penelitian selanjutnya adalah "Strategi Komunikasi Risiko Kementerian Kesehatan Republik Indonesia dalam Upaya Penanggulangan Covid-19 Melalui Media Sosial" yang menemukan bahwa penggunaan media sosial untuk mengatasi COVID-19 oleh Kementerian Kesehatan Republik Indonesia belum dilakukan secara efektif karena masih ada prinsip dan elemen komunikasi risiko yang telah diabaikan (Sri \& Indra, 2021). Oleh karena itu, dalam penelitian ini mengkaji tentang elemen komunikasi risiko yang bagaimana perlu diterapkan sehingga penting untuk melakukan komunikasi risiko, terkhusus konten terkait anak jika terjadi kondisi pandemi di masa depan.

Jika diperhatikan, tidak ada satupun penelitian yang membahas tentang bagaimana komunikasi risiko tentang kesehatan anak yang dilakukan oleh akun komunitas virtual parenting. Padahal, konten terkait komunikasi risiko tentang kesehatan anak menjadi sesuatu yang tidak kalah penting dibutuhkan oleh khalayak, terkhusus para orang tua yang peduli akan kesehatan anaknya di masa pandemi Covid-19, sehingga peneliti melihat bahwa mengangkat topik terkait komunikasi risiko tentang kesehatan anak adalah menarik untuk dikaji karena belum pernah dilakukan sebelumnya. Selain itu, penelitian yang mencoba mengungkapkan bagaimana unsur strategi unggahan postingan ditinjau dari tiga kajian, yakni tema, fungsi, dan bentuk penting untuk dilakukan guna manjadi panduan persiapan bagi komunitas virtual dalam menghadapi masa pandemi baik saat ini maupun potensial bencana pandemi di masa mendatang. Dalam konsep komunikasi pembangunan, memberikan segala upaya, cara dan teknik penyampaian gagasan dan keterampilan pembangunan yang berasal dari pihak yang memprakarsai pembangunan kepada masyarakat yang menjadi sasaran, agar dapat memahami, menerima dan berpartisipasi dalam pembangunan. Konsep ini sejalan dengan kajian penelitian yang berusaha untuk mengemukakan strategi menyampaikan komunikasi risiko terkait konten anak yang dikemas secara efektif dan efisien dengan studi komunitas pola asuh virtual di Instagram. Penelitian ini dapat menjadi rujukan bagi komunitas virtual pola asuh lainnya untuk dapat berpartisipasi dan bertanggungjawab dalam membantu membangun pemahaman masyarakat yang baik terkait komunikasi risiko dengan konten khusus tentang anak. Pembangunan nasional akan terwujud dengan baik apabila adanya suatu media komunikasi yang berbentuk jejaring sosial yang digunakan masyarakat dengan benar, beretika dan dapat dipertanggungjawabkan kebenarannya (Suri, 2018).

Dalam penelitian ini akan menganalisis bagaimana strategi komunikasi risiko yang dilakukan oleh komunitas parenting atau sekelompok orang tua yang memiliki anak, dimana dapat dikelompokkan menjadi tiga golongan, yaitu golongan usia bayi (0-2 tahun), golongan batita (2-3 tahun) dan golongan prasekolah (>3-6 tahun) (Adriani \& Bambang, 2014). Para orang tua dalam komunitas parenting memiliki tingkat kepedulian yang tinggi untuk mengurangi dampak risiko penyebaran virus COVID19, dengan tujuan yang lebih khusus, yakni menerapkan perilaku protektif atau untuk melindungi kesehatan anak-anaknya dari rantai penyebaran virus COVID-19. Komunikator risiko yang menyebarkan konten informasi seputar pengetahuan parenting selama masa pandemi yang akan dianalisis dalam penelitian ini, memanfaatkan platform Instagram dalam melaksanakan komunikasi risikonya.

Beberapa akun Instagram komunitas virtual parenting yang menjadi unit analisis dalam penelitian ini adalah@ayahbunda_;@parentalk.id; dan@gaiaparenting. Komunitas virtual adalah sekelompok orang di dunia maya yang memiliki minat yang sama. Anggota dari komunitas ini secara bebas saling bertukar pikiran, pandangan, dan informasi melalui berbagai medium seperti email, chatting, mailing list, atau bulletin boards. Komunitas virtual yang dipilih sebagai unit analisis dalam penelitian ini ditandai dengan adanya bentuk saling interaksi di dunia maya Instagram yang membahas tentang ketertarikan yang sama, yakni kesehatan anak. Dalam hasil survei yang bertajuk 'COVID-19 Barometer: Consumer Attitudes, Media Habits and Expectations' mengungkapkan bahwa selama masa pandemi Covid-19, terjadi peningkatan sebesar 50\% konsumsi masyarakat terhadap sosial media seperti Facebook, WhatsApp, Instagram (Kantar, 2020). Artinya, kebutuhan masyarakat akan informasi di kala pandemi meningkat dengan pesat, termasuk di Indonesia. Laporan Napoleon Cat, organisasi khusus yang menganalisis kinerja media sosial, menunjukkan bahwa terdapat $38.5 \%$ perempuan dan 33.4\% laki-laki, kelompok usia 18-54 tahun di Indonesia merupakan pengguna aktif Instagram. Jika dirincikan, pengguna aktif Instagram untuk kelompok usia tersebut adalah 65,4 juta dari total pengguna aktif 91,01 juta. Kelompok usia ini merupakan kelompok usia para orang tua di Indonesia (Cat, 2020). Tingginya angka pengguna aktif Instagram pada kelompok usia tersebut mengindentifikasikan bahwa menggunakan Instagram sebagai medium untuk menyasar para orang tua 
dalam menyampaikan informasi mengenai komunikasi risiko tentang anak adalah hal yang tepat untuk dilakukan.

\section{METODE PENELITIAN}

Paradigma yang digunakan pada penelitian ini adalah paradigma konstruktivisme. Dalam paradigma konstruktivisme sosial menyatakan bahwa para individu secara berkala menciptakan struktur sosial melalui aksi dan interaksi mereka, karenanya, tidak terdapat kebenaran abstrak atau realita, karena realita ada ketika terdapat orang yang menciptakannya secara bersama-sama (West et al., 2008). Penelitian ini menggunakan metode kualitatif dengan pendekatan netnografi, karena permasalahan berhubungan dengan manusia, yaitu spesifiknya adalah komunitas virtual yang secara fundamental bergantung pada pengamatan di dunia maya. Moleong menyatakan bahwa pendekatan kualitatif adalah penelitian yang bermaksud untuk memahami fenomena tentang apa yang dialami oleh subjek penelitian misalnya perilaku, persepsi motivasi, tindakan, dan lain-lain secara holistik dan dengan cara deskripsi dalam bentuk kata-kata atau bahasa, pada suatu konteks khusus yang alamiah dan dengan memanfaatkan metode alamiah (Moleong, 2017).

Metode netnografi merupakan pendekatan baru melalui riset etnografik yang menggabungkan arsip dan interaksi secara online, membutuhkan pengamatan dan observasi, dalam bentuk pengumpulan data secara digital, analisis dan representasi riset (Kozinets, 2015). Dalam metode netnografi, peneliti sebagai instrumen penelitian bukan hanya sekadar mengategorikan data dari postingan media sosial semata, tetapi lebih dalam lagi menggambarkan dan menguraikan sosialitas dari kehidupan online (Kozinets \& Gambetti, 2021).

Unit analisis dalam penelitian ini merupakan postingan periode Maret 2020-September 2021 yang memenuhi kriteria berdasarkan konsep yang telah dirumuskan dalam penelitian, yakni mengandung informasi terkait komunikasi risiko tentang kesehatan anak di masa pandemi Covid-19. Periode ini dipilih berdasarkan pertimbangan awal mula kondisi pandemi Covid-19 di Indonesia yang mulai melahirkan konten komunikasi risiko tentang kesehatan anak dengan segmentasi pasar para orang tua yang khawatir dengan kesehatan anaknya, sedangkan bulan September, dipilih sebagai akhir dari periode penelitian ini karena merupakan limitasi yang ditentukan mengingat pada bulan ini merupakan proses awal kajian dari penelitian.

Postingan yang menjadi kajian penelitian didapatkan melalui unggahan yang dilakukan oleh tiga akun komunitas virtual Instagram parenting profesional, yakni akun pertama adalah @ayahbunda merupakan akun parenting pertama di Indonesia yang memprakarsai strategi komunikasi pola asuh melalui Instagram, akun ini memiliki kredibilitas tinggi di tengah masyarakat, terbukti dari jumlah pengikutnya yang mencapai 190 ribu pengguna akun Instagram dan telah mendapatkan tanda centang biru yang artinya akun ini telah mendapatkan verifikasi dan resmi dari pihak Instagram. Kehadiran tanda centang biru ini juga membuktikan bahwa akun tersebut merupakan akun riil yang dapat dipercaya oleh masyarakat.

Akun Instagram kedua, @parentalk.id, yang menjadi fokus penelitian kami juga tidak kalah memiliki kredibilitas yang tinggi dengan jumlah pengikut sebanyak 944 ribu pengguna akun Instagram. Sama seperti akun komunitas virtual sebelumnya, akun@parentalk.id juga memiliki tanda centang biru, yang artinya telah diverifikasi secara resmi dan informasi yang disampaikan adalah benar dan dapat dipercaya oleh masyarakat.

Akun Instagram ketiga adalah @gaia_parenting, dengan jumlah pengikut 260 ribu, akun ini kami pilih berdasarkan karakteristik pengikut akun tersebut yang lebih aktif, terutama dalam postingan yang ingin penelitian kami kaji dibandingkan dua akun sebelumnya. Walaupun tidak memiliki tanda centang biru, namun kami melihat bahwa tingkat keaktifan pengikut akun ini lebih besar dari kedua akun sebelumnya, hal ini dibuktikan dari engagement unggahan komunikasi tentang risiko anak yang dilakukan oleh@gaia_parenting lebih banyak mendapatkan respon berupa suka dan komentar dibandingkan kedua akun sebelumnya, sehingga atas landasan tersebut, akun@gaia_parenting dipilih menjadi unit analisis kajian dalam penelitian.

Hasil dari ketiga akun instragram tersebut ditemukan terdapat 55 data postingan yang sejalan dengan teori dan konsep. Namun, dari data gambar dan video tersebut dilakukan proses reduksi berdasarkan kelayakkan unit analisis ditinjau dari engagement postingan. Hasilnya, telah didapatkan sebanyak 30 postingan yang akan menjadi bahan analisis data. Data yang telah dikumpulkan kemudian dilakukan 
uji reabilitas untuk melihat nilai coefisient reability melalui rumus Holsty, sehingga didapatkan alat ukur yang reliabel dengan korelasi kesepakatan yang tinggi.

Teknik analisis data dalam penelitian ini dilakukan melalui langkah open coding, yakni menguraikan, memeriksa, membandingkan, mengonsepkan dan mengategorikan hal-hal yang ditemukan dalam postingan. Dalam tahapan open coding, peneliti fokus untuk menguraikan konten berdasarkan waktu dan memasukkannya dalam tabel yang telah dilakukan kategori, dengan detail sebagai berikut:

(a) Unsur strategi tema, kode PRV untuk 'Upaya preventif melindungi anak dari paparan virus Covid19', PDN untuk 'Panduan merawat anak yang terjangkit virus Covid-19', UTD untuk 'Update informasi terkait Covid-19 terhadap anak', DMK untuk 'Dampak pandemi Covid-19 terhadap kondisi anak', dan CRT untuk 'Cerita terkait anak di masa pandemi Covid-19'. Unsur strategi tema yang dimaksud dalam penelitian ini adalah pengelompokkan jenis-jenis konten komunikasi risiko yang dipilih berdasarkan unggahan konten yang telah dilakukan oleh komunitas virtual parenting untuk dalam kategori tertentu;

(b) Unsur strategi fungsi, kode IFM untuk 'Informatif', EKF untuk 'Edukatif', dan MTF untuk 'Motivatif'. Unsur strategi fungsi menjelaskan tentang bagaimana tanggung jawab komunikasi yang dijalankan komunitas virtual sebagai agen gerakan sosial. Ketiga unsur strategi fungsi ini dipilih berdasarkan rujukan penelitian terdahulu yang mengkategorikan fungsi dalam informatif, edukatif, dan motivative;

(c) Unsur strategi bentuk, kode PTO untuk 'Photo', kode VDO untuk 'Video', kode IGV untul 'IGTV', dan kose RLS untuk 'Reels'. Unsur strategi bentuk menjelaskan tentang bagaimana fitur yang diterapkan oleh komunitas virtual parenting dalam mengemas informasi terkait komunikasi risiko tentang kesehatan anak selama masa pandemi di Instagram. Bentuk ini dipilih berdasarkan kajian peneliti terhadap fitur-fitur dominan yang digunakan oleh komunitas virtual parenting yang menjadi unit analisis penelitian.

Langkah selanjutnya melakukan axial coding, yakni melakukan penempatan data kembali dengan cara-cara yang baru sehingga membuat ada keterikatan antar kategori. Dalam langkah ini, peneliti melakukan proses reduksi informasi yang penting untuk kemudian dimasukkan dalam tabel keterangan atau temuan dalam indikator tertentu pada tiap-tiap dimensi unsur strategi. Langkah analisis terakhir adalah selective coding, yakni langkah menyeleksi kategori-kategori guna menemukan kategori inti atau sentral untuk merangkai dan mengintegrasikan kategori-kategori lain dalam sebuah jaringan. Dalam proses selective coding, temuan dalam penelitian kembali di reduksi untuk memastikan bahwa informasi-infomrasi yang dimasukkan dalam penelitian ini adalah informasi yang benar-benar penting untuk diketahui oleh masyarakat. Dalam proses ini juga dilakukan penggabungan informasi yang telah didapatkan sehingga menarik sebuah kesimpulan untuk tiap-tiap unsur strategi yang menjadi fokus dalam kajian penelitian. Selama proses pengumpulan juga telah dilakukan analisis melalui triangulasi multiple times, yakni memastikan data tersebut tetap sama ditinjau dari waktu yang berbeda-beda untuk memastikan bahwa data yang didapatkan tersebut memiliki kredibilitas tinggi sehingga layak untuk dianalisis.

\section{HASIL DAN PEMBAHASAN}

Tabel 1 merupakan rangkuman besaran hasil frekuensi dan persentase dalam unit analisis kajian yang telah dimasukkan berdasarkan klasifikasi unsur strateginya. Hasil kajian analisis dalam penelitian ini mengungkapkan beberapa penemuan. Temuan pertama adalah bahwa terdapat korelasi antara dampak pandemi Covid-19 terhadap kesehatan anak yang menjadi konsentrasi tersendiri bagi masyarakat, khususnya para orang tua yang khawatir akan kondisi anaknya di masa pandemi. Konsentrasi ini dibuktikan melalui adanya konten khusus tentang kesehatan anak yang dibuat oleh ketiga komunitas virtual parenting yang merupakan unit analisis dalam penelitian. Komunikasi risiko dimaksudkan untuk menyampaikan pesan-pesan risiko untuk meningkatkan kesadaran, pemahaman, dan menggerakkan khalayak untuk bertindak (Covi \& Kain, 2016).

Komunitas virtual parenting dalam hal ini melihat bahwa masyarakat perlu mendapatkan informasi terkait dengan komunikasi risiko tentang kesehatan anak agar dapat melakukan upaya preventif, pengendalian, dan perawatan kepada anak di masa pandemi Covid-19. Sayangnya, konten komunikasi risiko tentang kesehatan anak yang dilakukan oleh ketiga akun komunitas virtual parenting masih belum dipaparkan secara masif alias masih dianggap sebagai konten sampingan diantara banyaknya pembahasan mengenai pola asuh anak. 
Tabel 1. Frekuensi dan Persentase Strategi Postingan

\begin{tabular}{cclcc}
\hline No & \multicolumn{1}{c}{ Strategi } & Frekuensi & Persentase \\
\hline 1 & Tema & Upaya preventif melindungi anak dari paparan virus & 13 Unsur & $14.4 \%$ \\
& & & \\
& Covid-19 (PRV) & \\
& Panduan merawat anak yang terjangkit virus Covid- & 8 Unsur & $8.8 \%$ \\
& 19 (PDN) & & \\
& Update informasi terkait Covid-19 terhadap anak & 5 Unsur & $5.5 \%$ \\
& (UTD) & & \\
& Dampak pandemi Covid-19 terhadap kondisi anak & 2 Unsur & $2.2 \%$ \\
& (DMK) & 2 Unsur & $2.2 \%$ \\
& Cerita terkait anak di masa pandemi Covid-19 (CRT) & 18 Unsur & $20 \%$ \\
& Fungsi & Informatif (IFM) & 10 Unsur & $11.1 \%$ \\
& Edukatif(EKF) & 2 Unsur & $2.2 \%$ \\
& Motivatif (MTF) & 23 Unsur & $25.5 \%$ \\
& Bentuk & Foto atau Gambar (PTO) & 3 Unsur & $3.3 \%$ \\
& Video (VDO) & 3 Unsur & $3.3 \%$ \\
& IGTV(IGV) & 1 Unsur & $1.1 \%$ \\
\hline & Reels (RLS) & 90 Unsur & $100 \%$ \\
\hline
\end{tabular}

Dari hasil penelitian ini, peneliti menghitung secara manual, menemukan bahwa dari total seluruh postingan unggahan ketiga akun komunitas virtual, yakni sebanyak 4136 postingan periode Maret 2020-September 2021 hanya terdapat 30 postingan yang memuat pesan tentang komunikasi risiko tentang kesehatan anak. Artinya, dalam periode tersebut, hanya terdapat persentase sebesar $0.72 \%$ postingan yang termasuk dalam konsep komunikasi risiko tentang kesehatan anak.

Melihat dari data ini, dapat dikatakan proses komunikasi risiko tentang kesehatan anak masih belum terjalan dengan baik. Padahal menurut Beck, risiko berarti mengantisipasi bencana dan menyangkut kemungkinan kejadian dan perkembangan di masa depan. Risiko menghadirkan keadaan atau kondisi yang belum ada. Jadi kategori risiko menandakan realitas kontroversial dari kemungkinan, yang harus dibatasi hanya dari kemungkinan spekulatif, di satu sisi, dan dari terjadinya bencana yang sebenarnya, di sisi lain. Saat risiko menjadi nyata, maka sejak itulah bencana terjadi (Beck, 2009). Oleh sebab itu, pada dasarnya penting untuk menjadikan konten kesehatan anak menjadi sebuah segmentasi khusus bagi para komunitas virtual parenting dalam mengimplementasikan komunikasi risiko guna menghindari bencana dampak pandemi yang tidak diinginkan menyasar pada anak-anak. Pada akhirnya, komunikasi risiko yang baik akan membantu penanganan risiko dengan baik pula, sehingga meminimalisir terjadinya kejadian yang tidak diinginkan, dalam hal ini khusus terkait kesehatan anak.

Temuan kedua dalam hasil kajian analisis penelitian ini mengungkapkan bahwa dari segi unsur strategi tema, upaya preventif melindungi anak dari paparan virus Covid-19 merupakan bahan diskusi yang paling banyak dijadikan konten oleh ketiga akun komunitas virtual parenting. Tujuan komunikasi risiko juga dapat berbeda dari komunikasi teknis. Dalam situasi berbahaya, seperti pandemi, komunikasi risiko yang dilakukan organisasi harus dapat bersifat memotivasi khalayak untuk melakukan tindakan (Patrianti et al., 2020). Tujuan ini menjelaskan mengapa tema upaya preventif melindungi anak dari paparan virus Covid-19 menjadi tema yang paling banyak dijadikan konten komunikasi risiko tentang kesehatan anak. Hal ini terjadi, karena pada dasarnya konten dengan tema upaya preventif melindungi anak dari paparan virus Covid-19 berisikan tentang pemaparan informasi sekaligus pemberian edukasi yang mengarahkan para orang tua kepada langkah-langkah penting yang harus dilakukan untuk mencegah terjadinya kasus positif pandemi Covid-19 pada anak.

Tema ini juga sejalan dengan empat bidang yang menunjukkan bagaimana komunikasi risiko diterapkan: (1) informasi dan pendidikan - dimana orang diberi informasi dan dididik tentang risiko; (2) merangsang perubahan perilaku dan mengambil tindakan perlindungan, melalui pengurangan risiko dengan mempengaruhi persepsi khalayak; (3) peringatan bencana dan informasi darurat, yang memberikan instruksi dan panduan selama bencana dan keadaan darurat; dan (4) pertukaran informasi dan pendekatan umum untuk masalah risiko,yang melibatkan masyarakat dalam proses manajemen risiko. Berbagai jenis risiko akan memerlukan berbagai bentuk komunikasi risiko (Ndlela, 2019). Hal yang perlu diperhatikan adalah seberapa efektifkah penyampaian komunikasi risiko dengan tema ini mampu membujuk khalayak untuk melakukan suatu tindakan. Selaras dengan kutipan Ndlela, yang 
menyatakan bahwa salah satu tantangan terbesar yang dihadapi komunikator risiko adalah memotivasi, membujuk, atau memengaruhi pemangku kepentingan. Untuk menjawab pertanyaan tersebut, nantinya akan dijelaskan mengenai engagement dan resepsi publik yang telah dijabarkan dalam paragraf khusus di bawah ini tentang analisis unsur strategi tema yang telah dilakukan oleh ketiga akun komunitas virtual (Ndlela, 2019).

Temuan ketiga, menunjukkan bahwa unsur infomatif merupakan strategi fungsi yang paling banyak dibuat menjadi konten oleh komunitas virtual parenting. Komunikasi risiko merupakan pendekatan yang berbasis sains untuk berkomunikasi secara efektif dalam situasi apapun. Komunikasi risiko itu sendiri pada dasarnya merupakan proses pertukaran informasi dan opini interaktif antara individu, kelompok dan institusi. Hal ini menegaskan mengapa strategi konten unsur informatif merupakan fungsi yang paling utama diolah menjadi konten dalam komunitas virtual parenting. Selain itu, kebutuhan informasi menjadi hal yang sangat penting bagi masyarakat di tengah pandemi. Kehausan masyarakat akan informasi mengenai hal apa yang sedang terjadi membuat komunitas virtual parenting melihat hal tersebut sebagai sebuah peluang unsur konten yang tentunya akan mendapatan perhatian yang besar dari masyarakat.

Hal yang perlu diperhatikan dalam penyampaian informasi dari sudut pandang komuniaksi risiko adalah adanya trust dari sumber informasi terpercaya, seperti pemerintah, pakar/ahli, atau organisasi nonprofit yang memiliki kredibilitas tinggi. Sumber informasi yang kredibel akan meinimbulkan kepercayaan publik sehingga pada akhirnya, proses mitigasi bencana akan mudah dilakukan (Rajib, 2013). Merujuk pada pernyataan hal yang harus diperhatikan tersebut, hasil penelitian ini melihat bahwa ketiga akun komunitas virtual parenting telah memasukkan unsur trust dalam setiap kontennya. Unsur trust yang paling banyak ditemui oleh peneliti dalam konten yang diunggah adalah hasil diskusi bersama pakar/ahli kesehatan yang telah melakukan kajian atau penelitian tentang kesehatan anak.

Peneliti juga melihat bahwa unsur trust ini sebenarnya tidak mempengaruhi peningkatan engagement postingan secara signfikan. Akan tetapi, peneliti melihat bahwa memang apabila sebuah postingan ditambahkan keterangan sumber yang memiliki kredibilitas tinggi akan mengundang banyak diskusi dan juga membentuk persepsi yang baik dari publik, yakni ditemukannya komentar-komentar yang bernada setuju dengan postingan yang memiliki sumber kredibilitas yang tinggi. Hasil penelitian juga menunjukkan bahwa dari 30 postingan komunikasi risiko tentang kesehatan anak yang diunggah oleh ketiga komunitas virtual, terdapat sebanyak 20 postingan yang memasukkan unsur trust. Artinya, setiap postingan yang diunggah oleh ketiga akun komunitas virtual dikemas dengan mengandung informasi yang berdasar dari sumber terpercaya yang berkaitan dengan komunikasi risiko terkait kesehatan anak di masa pandemi, seperti dari Ikatan Dokter Anak Indonesia (IDAI) atau website resmi covid.go.id.

Temuan keempat dalam hasil penelitian ini adalah unsur strategi bentuk komunikasi risiko tentang kesehatan anak yang palng banyak digunakan adalah foto. Hal yang paling nampak, mengapa foto dijadikan sebagai bentuk yang paling utama adalah kemudahan dalam proses pemuatan informasi dibandingkan dengan bentuk yang lainnya. Dalam bentuk foto, informasi disampaikan dalam format kata-kata serta penambahan elemen lainnya berupa animasi maupun graphics interchange format (GIF) yang mudah untuk ditambahkan. Berbeda dengan bentuk video maupun IGTV, yang mengharuskan seseorang dengan secara langsung menjelaskan maksud dan tujuan dari pesan yang ingin disampaikan. Selain itu, mengapa bentuk video ataupun IGTV tidak terlalu banyak digunakan oleh komunitas virtual parenting dalam mengolah pesan komunikasi risiko tentang kesehatan anak disebabkan karena dalam video sendiri perlu upaya yang tidak mudah untuk mendapatkan engagement yang tinggi. Oliver Foo, VP Business Development \& COE Programme Singtel 87 International Group, menyarankan bahwa durasi 3-5 menit adalah waktu ideal bagi para penonton ketika mengkonsumsi video pada media sosial (Rachmatunnisa, 2016). Artinya, jika komunitas virtual parenting ingin menyampaikan pesan komunikasi risiko tentang kesehatan anak dalam bentuk video maupun IGTV, maka harus diperhatikan bahwa durasi 3 menit awal akan menarik bagi khalayak atau penting bagi mereka untuk menyimak pesan dalam video tersebut. Apabila gagal, maka kemungkinan besar khalayak tidak akan meneruskan aktivitas menonton video tersebut, sehingga pesan komunikasi risiko tentang kesehatan anak yang hendak disampaikan tidak tersalurkan dengan baik kepada khalayak.

Berbeda halnya dengan foto, fitur multiple slide share atau disebut juga carousel, memungkinkan para khalayak menggeser slide foto untuk mendapatkan informasi yang diinginkan. Tidak ada batasan waktu bagi khalayak untuk melihat informasi tersebut, selama mereka ingin melakukannya. Akan 
tetapi, sebenarnya terdapat sebuah solusi yang menarik untuk permasalahan durasi video yang perlu diperhatikan untuk menjangkau khalayak, yakni menggunakan fitur Instagram reels yang hanya menyampaikan pesan dalam durasi maksimal 60 detik. Fitur ini masih belum dimanfaatkan secara maksimal oleh komunitas virtual parenting dalam membuat pesan komunikasi risiko tentang kesehatan anak. Hasil penelitian menunjukkan hanya terdapat 1 dari 30 postingan unit analisis penelitian yang menggunakan fitur Reels Instagram. Padahal, tools Reels yang memiliki elemen untuk memadukan musik (backsound), running teks, efek, cut scene, pengaturan kecepatan, dan masih banyak lagi tools lainnya yang terdapat dalam Reels, mampu membuat sebuah cara kreatif dalam menyampaikan pesan komunikasi risiko tentang kesehatan anak. Peneliti melihat bahwa terdapat potensi yang besar pada penggunaan Reels, sebagai fitur untuk mengemas pesan komunikasi risiko tentang kesehatan anak. Hal ini didasari pada fakta bahwa postingan 1 dari 30 yang menggunakan fitur Reels tersebut mendapatkan engagement yang sangat tinggi, yakni 2,133 like dan 114 komentar.

\section{Unsur Strategi Tema}

Upaya Preventif Melindungi Anak Dari Paparan Virus Covid-19. Dalam unsur tema ini meliputi beberapa konten postingan yang disebarkan oleh komunitas virtual, yaitu ke tiga akun Instagram parenting dalam memberikan informasi terkait komunikasi risiko terhadap tindakan dan pengambilan keputusan yang tepat oleh orang tua mengenai cara atau upaya pencegahan agar anak dapat terlindungi dari paparan virus Covid-19.

Strategi unsur tema pertama ini mendapatkan engagement tinggi karena telah menerapkan konsep komunikasi risiko dengan baik, dimana isi konten postingan sifatnya penting untuk diketahui oleh khalayak, yaitu khususnya orang tua untuk mengetahui risiko kesehatan apa yang dihadapi, yakni seberapa bahaya pandemi Covid-19, bagaimana proses penularan virus pada anak dimana diketahui bukan hanya sekadar melalui droplets air liur tetapi bisa melalui feses saat anak mengalami diare, dan sudah berapa banyak jumlah kasus infeksi virus Covid-19 yang menimpa anak. Selain itu, postingan dengan strategi unsur tema ini juga berperan dalam meningkatkan kesadaran, pemahaman, dan memberikan pedoman bagi para orang tua untuk perubahan tindakan dan pengambilan keputusan yang tepat dalam upaya pencegahan untuk melindungi kesehatan anak-anaknya dari bahaya virus Covid-19, seperti tindakan mencegah orang lain untuk mencium dan memegang anak. Hasil persentase analisis dalam penelitian juga menunjukkan bahwa postingan dengan unsur tema ini mendapatkan jumlah yang tertinggi, yaitu sebesar $14.4 \%$. Dari hasil presentase tersebut menunjukkan bahwa strategi dengan unsur tema upaya preventif melindungi anak dari paparan virus Covid-19 merupakan unsur tema yang dibutuhkan dan diharapkan oleh khalayak. Gambar 1 adalah contoh dua postingan yang termasuk kedalam unsur tema pertama.
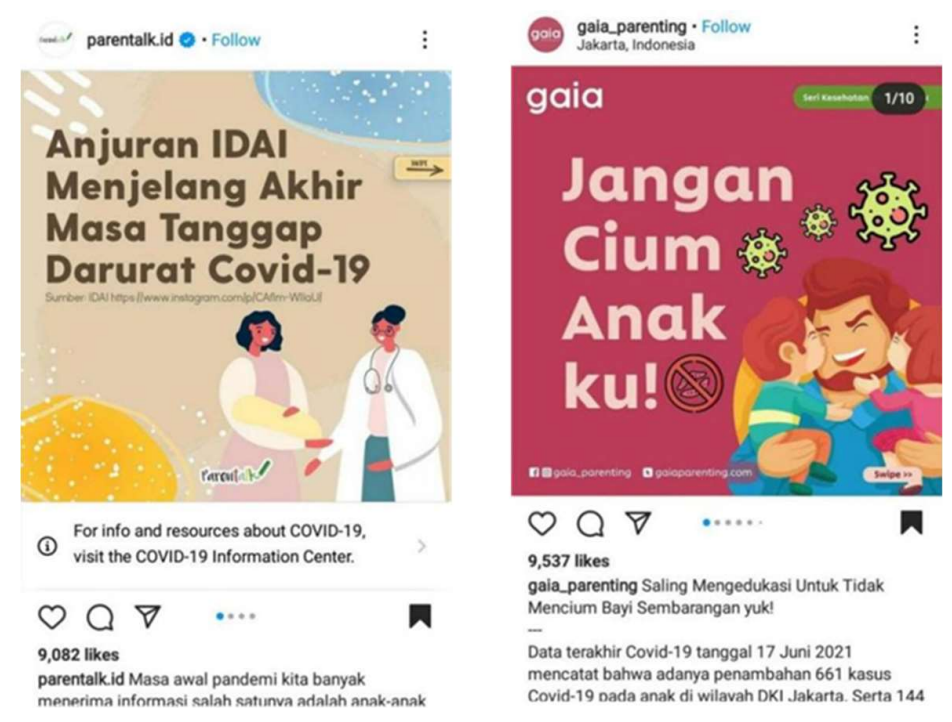

Gambar 1. Contoh postingan unsur tema upaya preventif melindungi anak dari paparan virus covid-

19. Sumber: instagram akun@parentalk.id dan@gaia_parenting

Adapun karakterisik dalam unsur tema ini adalah postingan bersifat memberikan informasi mengenai cara-cara preventif agar anak terlindungi dari infeksi virus, bagaimana menghadapi anak apabila 
bertanya tentang virus Covid-19, urgensi imunisasi untuk anak balita, urgensi vaksinasi untuk anak dan orang tua, penerapan perilaku yang mengaplikasikan protokol kesehatan, serta bagaimana cara ibu yang positif Covid-19 aman untuk menyusui, tetapi tetap mampu melindungi anaknya dari infeksi virus. Selain itu, karakteristik yang terlihat pada postingan dengan unsur tema ini adalah dikemas dengan menampilkan beberapa gambar karikatur orisinal yang beragam sebagai ciri khas dari tiga akun Instagram parenting. Selain itu, terdapat juga beberapa postingan yang dikemas menggunakan graphics interchange format (GIF) atau dapat diartikan sebagai gambar bergerak.

Hasil penelitian ini mengungkapkan, bahwa berdasarkan linimasa pengunggahan tiga belas konten bahan kajian penelitian terkait unsur tema upaya preventif melindungi anak dari paparan virus Covid19, menyimpulkan dapat disimpulkan bahwa waktu unggahan postingan terkait unsur tema ini yang dilakukan oleh ketiga akun komunitas virtual adalah ketika awal pandemi terjadi dan kejadian pascapandemi Covid-19.
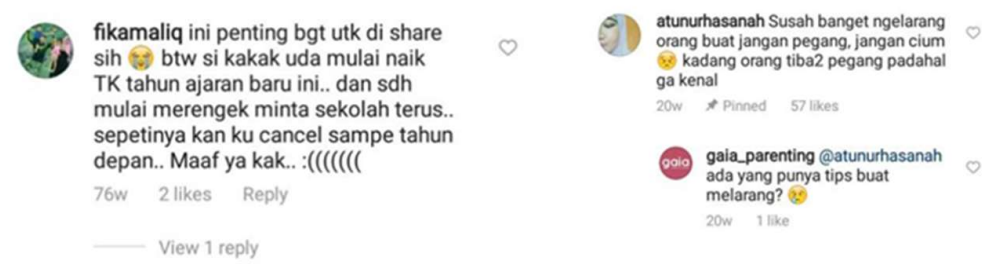

Gambar 2. Komentar dalam postingan@parentalk dan@gaia_parenting. Sumber: Instagram Akun @parentalk.iddan@gaia_parenting

Urgensi isi konten dari strategi unsur tema ini juga dapat dilihat dari percakapan para orang tua di kolom komentar terkait upaya preventif melindungi anak dari paparan virus Covid-19, yaitu salah satunya terkait memberikan imunisasi pada anak balita dan vaksinasi untuk anak, para orang tua yang menceritakan kondisi keluarganya saat ini, bagaimana tindakan pencegahan yang diterapkan, dan tips untuk menegur agar orang lain tidak mencium atau memegang anak di masa pandemi Covid-19. Gambar 2 merupakan contoh diskusi dari para orang tua terkait dengan upaya preventif melindungi anak dari paparan virus Covid-19.

Panduan Merawat Anak yang Terjangkit Virus Covid-19. Dalam strategi unsur tema panduan merawat anak yang terjangkit virus Covid-19 menitikberatkan fokus pembahasan komunikasi risiko pada langkah demi langkah tentang bagaimana penanganan yang harus dilakukan oleh orang tua untuk meringankan gejala dan tindakan tepat yang harus dilakukan ketika anak telah menunjukkan atau telah dikonfirmasi positif terjangkit Covid-19. Hasil persentase analisis dalam penelitian juga menunjukkan bahwa postingan dengan unsur tema ini mendapatkan jumlah persentase sebesar $8.8 \%$, membuat unsur tema ini menjadi kedua terbesar setelah unsur tema upaya preventif melindungi anak dari paparan virus Covid-19. Hal ini menunjukkan bahwa strategi dengan unsur tema panduan merawat anak yang terjangkit virus Covid-19 dapat menjadi pilihan tema yang menarik bagi komunitas virtual di Instagram yang hendak memproduksi konten khusus terkait dengan komunikasi risiko tentang kesehatan anak.

Adapun karakterisik dalam unsur tema ini adalah postingan bersifat memberikan langkah-langkah atau panduan yang dapat diterapkan oleh orang tua dalam memantau kondisi anak. Panduan tersebut dapat berupa cara mengenali gejala Covid-19 pada anak, panduan isolasi mandiri pada anak, pengaruh vaksin terhadap anak yang terindikasi Covid-19, penanganan Covid-19 pada anak yang tidak bergejala, apa saja tanda-tanda yang diperlihatkan oleh anak terindikasi Covid-19, serta peralatan apa saja yang dibutuhkan.

Hasil penelitian ini mengungkapkan, bahwa berdasarkan linimasa pengunggahan delapan konten bahan kajian penelitian terkait unsur panduan merawat anak yang terjangkit virus Covid-19, menyimpukan bahwa waktu unggahan postingan terkait unsur tema ini yang dilakukan oleh ketiga akun komunitas virtual dilakukan ketika pascapandemi. Gambar 3 (halaman berikutnya) merupakan contoh postingan yang memiliki engagement tinggi yang dilihat dari jumlah like mencapai lebih dari 2000 dan komentar lebih dari 250 dalam unsur tema ini. 

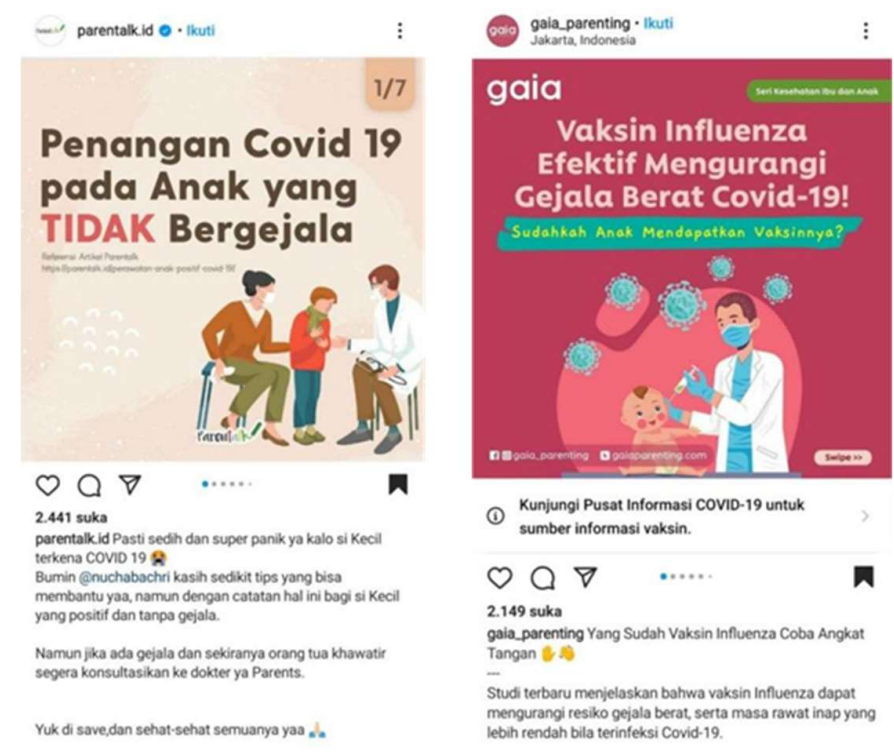

Gambar 3. Contoh postingan unsur tema panduan merawat anak yang terjangkit virus covid-19.

Sumber: instagram akun@parentalk.id dan@gaia_parenting

Postingan dengan unsur strategi tema ini mendapatkan engagement yang tinggi karena dianggap memberikan manfaat yang besar bagi masyarakat, terutama bagi orang tua yang mengalami serangan panik ketika anaknya terindikasi positif Covid-19, atau orang tua yang sekadar membutuhkan informasi jika seandainya suatu hari anaknya terjangkit virus Covid-19. Engagement yang paling tinggi dalam konten postingan tema ini mencapai 2,148 like dan 262 komentar. Gambar 4 dibawah ini merupakan contoh diskusi dari para orang tua terkait dengan panduan merawat anak yang terjangkit virus Covid-19.

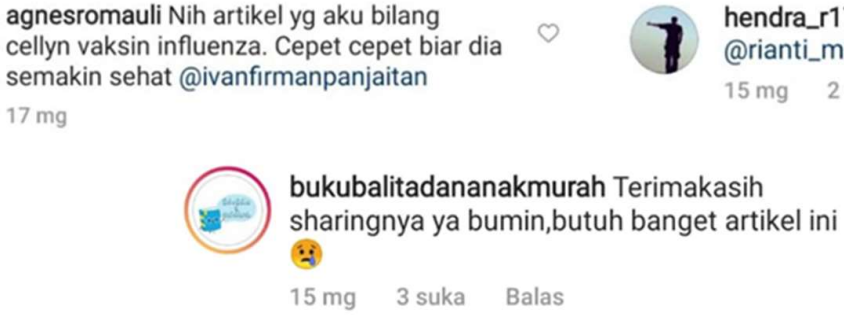

bukubalitadananakmurah Terimakasih sharingnya ya bumin,butuh banget artikel ini (4) $15 \mathrm{mg} \quad 3$ suka Balas

Gambar 4. Komentar dalam postingan@parentalk dan@gaia_parenting. Sumber: Instagram Akun @parentalk.id dan@gaia_parenting

Update Informasi Terkait Covid-19 Terhadap Anak. Unsur tema yang ketiga adalah update informasi terkait Covid-19 terhadap anak, merupakan strategi produksi konten yang memfokuskan untuk menginformasikan berita terbaru dan terkini seputar virus Covid-19 yang berhubungan dengan anak. Hasil persentase dalam analisis penelitian menunjukkan bahwa postingan dengan tema update informasi terkait virus Covid-19 terhadap anak menempati posisi yang rendah jika dibandingkan dengan tema-tema lainnya, yakni hanya terdapat lima postingan dengan persentase $5.5 \%$, menjadikan unsur tema ini menempati posisi ketiga dibandingkan tema lainnya. Hal ini disebabkan karena memang pada dasarnya fokus dari komunikasi risiko tentang kesehatan anak adalah penjelasan terkait upaya preventif dan juga panduan merawat anak positif terjangkit Covid-19, tetapi informasi terbaru sebenarnya banyak diminati dan menjadi perhatian para orang tua terbukti dengan engagement tinggi yang diperoleh khususnya terkait uji coba vaksinasi virus Covid-19 terhadap anak.

Karakteristik dari postingan unsur tema update informasi terkait virus Covid-19 terhadap anak adalah mengutamakan mengemas informasi yang berdasarkan data tertentu, seperti data kasus infeksi Covid19 yang disampaikan oleh para pakar dan ahli melalui diskusi bersama secara live Instagram dengan akun parenting. Selain itu, berisikan berita-berita terbaru terkait virus Covid-19 yang erat hubungannya dengan anak, seperti informasi vaksinasi terbaru (pfizer dan moderna) untuk anak, 
informasi ini juga dikutip berdasarkan penelitian yang kebanyakkan dilakukan di Amerika Serikat. Berikut di bawah ini Gambar 5 adalah contoh postingan dari unsur tema ini.
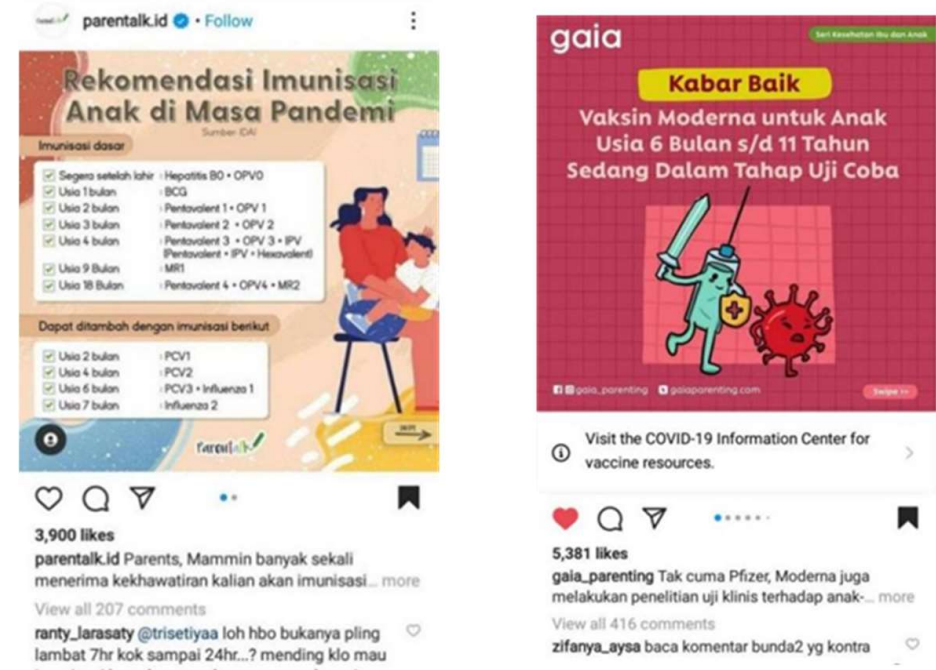

Gambar 5. Contoh postingan update informasi terkait covid-19 terhadap anak. Sumber: instagram akun@parentalk.iddan@gaia_parenting

Hasil penelitian ini mengungkapkan, bahwa berdasarkan linimasa pengunggahan lima konten bahan kajian penelitian terkait unsur update informasi terkait Covid-19 terhadap anak, menyimpulkan bahwa waktu pengunggahan postingan yang tepat adalah ketika kasus Covid-19 meningkat, karena memberitakan informasi terbaru terkait jumlah data kasus Covid-19 pada anak dan ketika kasus Covid-19 sudah sedikit menurun dimana pada saat telah banyak ditemukan vaksin untuk pencegahan virus.

Kolom komentar pada postingan di tema ini banyak dijadikan wadah untuk berdiskusi dan mengeluarkan pendapat. Seperti postingan mengenai uji coba vaksinasi virus Covid-19 terhadap anak banyak menjadi pro dan kontra, terdapat orang tua yang mendukung dan juga menolak memberikan vaksinasi terhadap anaknya. Hal tersebut dapat dilihat dari contoh komentar di bawah ini. Gambar 6 (halaman sebelumnya) merupakan contoh diskusi dari para orang tua terkait dengan update informasi terkait Covid-19 terhadap anak. Berikut (halaman selanjutnya) merupakan contoh komentar pro dan kontra dalam postingan dengan unsur tema ini :

"lucu baca komentar yang kontra, orang jelas2 masih uji klinis. kandungannya juga mungkin beda gak sama kayak yg dewasa.. moderna/pfizer itu kan pabriknya.. lagian takut anak di suntik lha emangnya gak imunisasi tah? masih lama juga itu paling taun depan.. makanya dibaca ampe abis jangan judulnya doang....)" (@febryca.rei)

“untuk anak kok cobacoba ;)”(@aisyahza22)

Dampak Pandemi Covid-19 Terhadap Kondisi Anak. Unsur tema berikutnya, yakni dampak pandemi Covid-19 terhadap kondisi anak merupakan strategi dalam memproduksi konten yang menekankan pada bagaimana pandemi Covid-19 memengaruhi psikologis dan perubahan pada jadwal atau kegiatan dalam pola kehidupan anak. Hasil persentase dalam analisis penelitian menunjukkan bahwa postingan dengan tema dampak pandemi Covid-19 terhadap kondisi anak menempati posisi yang rendah jika dibandingkan dengan tema-tema lainnya, yakni hanya terdapat dua postingan dengan persentase $2.2 \%$, menjadikan unsur tema ini menempati posisi keempat dibandingkan tema lainnya. Hal ini disebabkan karena memang pada dasarnya fokus dari komunikasi risiko tentang kesehatan anak adalah penjelasan terkait upaya preventif dan juga panduan merawat anak positif terjangkit Covid-19. Unsur tema dampak pandemi Covid-19 terhadap kondisi anak dapat menjadi pilihan alternatif bagi komunitas virtual akun Instagram dalam mengembangkan strategi konten terkait komunikasi risiko tentang kesehatan anak. Gambar 6 (halaman berikutnya) merupakan contoh postingan unsur tema ini. 

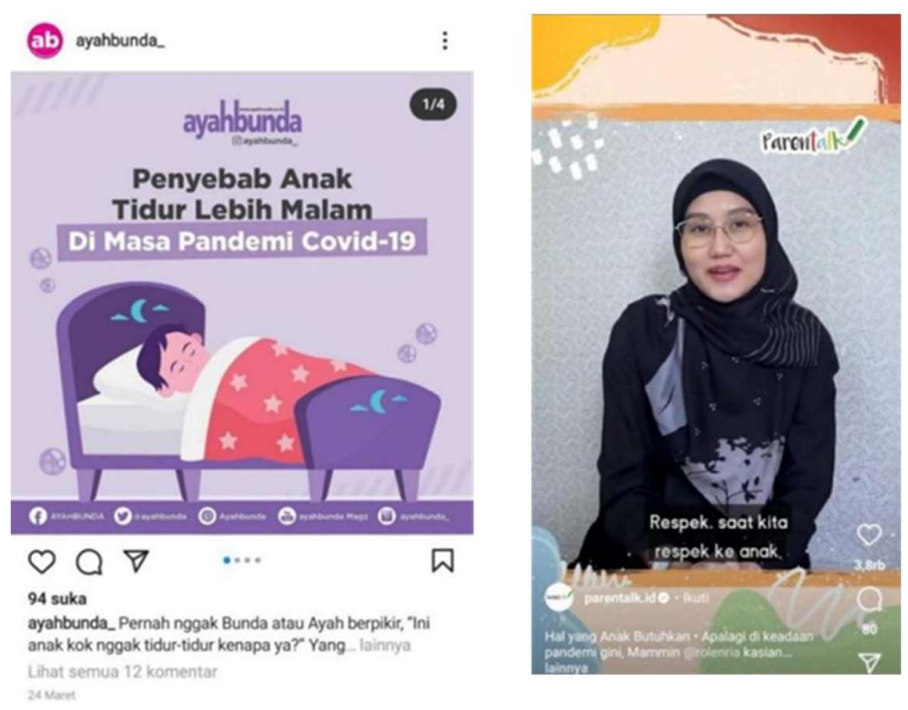

Gambar 6. Contoh Postingan Dampak Pandemi Covid-19 Terhadap Anak. Sumber: Instagram Akun @parentalk.iddan@ayah_bunda

Karakteristik dari postingan unsur tema dampak pandemi Covid-19 terhadap kondisi anak adalah isi dalam postingan menekankan pada hasil analisis atau penelitian mengenai perubahan psikologis, pola, jadwal atau kegiatan yang dialami oleh anak selama masa pandemi Covid-19. Karakteristik selanjutnya adalah pesan disampaikan oleh pakar atau orang yang ahli dibidangnya, misalnya dokter, psikolog, pakar anak, dan sebagainya. Jika ditinjau dari sisi lini masa pengunggahan postingan dengan unsur tema ini, maka waktu ketika pandemi sedang meningkat adalah masa yang cocok untuk mengunggah postingan. Hal ini mengingat bahwa postingan tersebut menyampaikan informasi terkait dampak Covid-19 terhadap anak yang terjadi saat masa pandemi, bukan sebelum terjadinya pandemi maupun setelah berakhirnya pandemi.

Sayangnya, postingan dengan unsur tema seperti ini masih sangat sedikit diproduksi oleh ketiga akun komunitas virtual. Padahal fokus akan dampak yang diakibatkan oleh pandemi juga menjadi topik menarik untuk dibicarakan. Hal ini dapat dilihat dari beberapa komentar dalam postingan tersebut yang mengindikasikan adanya perasaan setuju dengan apa yang telah diunggah oleh komunitas virtual terkait. Berikut (halaman berikutnya) merupakan contoh diskusi dari para orang tua terkait dengan dampak pandemi Covid-19 terhadap kondisi anak:

"Bener bgt, lebih sering ke nanya juga sih dia kenapa, maunya apa, gimana perasaannya dan dia sering bngt bilang "mami aku bosen" :D ditawarin yang lain ga mau, kan jadi sedih maminya ;) dia cuma mnta 1 "abang mau sekolah yang nyata ketemu teman trus mau main sama teman2 baru abang, ga kaya gini”,;) ;) mengsedih kan jadinya” (@rizka_rzklh)

"Seneng bgt tiap liat video maminn, padahal blm punya anak..lulus kuliah aja belomm :) ;) ;( but this is so informative and helpfulllll." (@sarahausxo)

Cerita Terkait Anak di Masa Pandemi Covid-19. Unsur tema yang terakhir adalah cerita terkait anak di masa pandemi Covid-19, unsur tema ini memfokuskan strategi produksi konten dengan memberikam cerita-cerita menarik dan biasanya bersifat inspiratif atau mendorong semangat untuk tetap berjuang melawan penyebaran virus Covid-19. Hasil persentase dalam analisis penelitian menunjukkan bahwa postingan dengan tema cerita terkait anak di masa pandemi Covid-19 menempati posisi yang rendah jika dibandingkan dengan tema-tema lainnya, yakni hanya terdapat dua postingan dengan persentase $2.2 \%$, jumlah persentase yang sama dengan unsur tema dampak pandemi Covid-19 pada kondisi anak. Sehingga, menjadikan unsur tema ini menempati posisi kelima dibandingkan tema lainnya. Hal ini disebabkan karena memang pada dasarnya fokus dari komunikasi risiko tentang kesehatan anak adalah penjelasan terkait upaya preventif dan juga panduan merawat anak positif terjangkit Covid-19. Gambar 7 (halaman berikutnya) adalah postingan unsur tema ini. 

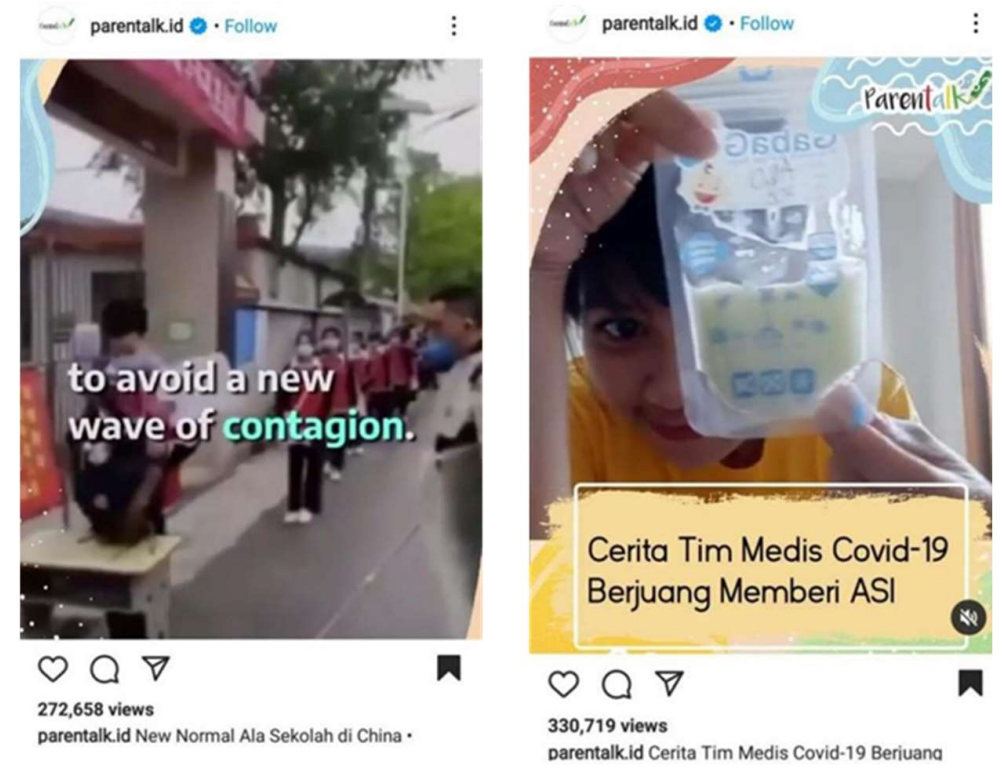

Gambar 7. Contoh postingan cerita terkait anak di masa pandemi covid-19. Sumber: Instagram Akun @parentalk.id

Karakteristik dari postingan unsur tema cerita terkait anak di masa pandemi Covid-19 adalah menampilkan cuplikan cerita yang memperlihatkan peristiwa nyata terkait situasi pandemi Covid-19 saat ini yang berkaitan dengan anak. Cerita ini dikemas dalam bentuk postingan IGTV dengan durasi 1-2 menit. Rentang perhatian khalayak media daring pendek, artinya khalayak di Instagram kebanyakkan cepat merasa bosan sehingga harus mengemas konten dengan unsur tema ini dengan durasi singkat, simple, tetapi memiliki nilai komunikasi risiko. Karakteristik format IGTV jug a penting, dimana kualitas kejernihan cerita dan audio pada IGTV yang dapat memengaruhi engagement khalayak. Jika ditinjau dari sisi lini masa pengunggahan postingan dengan unsur tema ini, maka waktu ketika kasus pandemi Covid-19 sedang meningkat hingga masa new normal adalah waktu yang cocok untuk mengunggah postingan.

Berikut di bawah ini adalah contoh komentar diskusi dari para orang tua di postingan dengan unsur tema cerita terkait anak di masa pandemi Covid-19.

"Kalau anak2 usia dini kayaknya harus ekstra bimbingan dari pihak sekolahnya min, kalau aja sekolah disini bisa mengikuti seperti itu pastinya kami orangtua tidak merasa khawatir melepasanak2untuksekolah kembali”(@its_me_yanti_)

"Walaupun sebenernya rada gimana gitu, buat bolehin anak untuk keluar \& sekolah lagi. Tapi saat nanti pemerintah udah bolehin untuk sekolah lagi, mau nggak mau kita harus banyak berinovasi biar si kecil tetap aman dan nyaman pas sekolah :D :D" (@kamoemontessori)

\section{Unsur Strategi Fungsi}

Fungsi Informatif. Unsur strategi fungsi informatif merupakan unsur strategi yang menekankan informasi berupa keterangan, gagasan maupun kenyataan yang perlu diketahui masyarakat (pesan yang disampaikan) dan dimanfaatkan seperlunya. Dalam unsur strategi fungsi informatif, masyarakat diharapkan mendapatkan berbagai informasi yang harus diketahui terkait dengan komunikasi risiko tentang kesehatan anak. Hasil persentase dari analisis penelitian menunjukkan bahwa persentase postingan yang termasuk dalam kategori unsur strategi fungsi informatif adalah sebesar $20 \%$ menjadikan strategi unsur ini sebagai jenis postingan paling banyak diaplikasikan oleh ketiga akun komunitas virtual. Hal ini dikarenakan banyak hal yang dapat disampaikan terkait dengan informasi komunikasi risiko tentang kesehatan anak, seperti informasi data Covid-19 pada anak, hal yang boleh dan tidak boleh dilakukan oleh orang tua kepada anak selama masa pandemi, informasi penting yang menyangkut kebutuhan di masa pandemi, perkembangan vaksin untuk anak, kenali gejala Covid-19 pada anak, rekomendasi imunisasi anak di masa pandemi, dan informasi lainnya terkait anak dan 
kesehatannya di masa pandemi Covid-19. Berikut di bawah ini merupakan contoh postingan yang termasuk dalam kategori unsur strategi fungsi informatif.

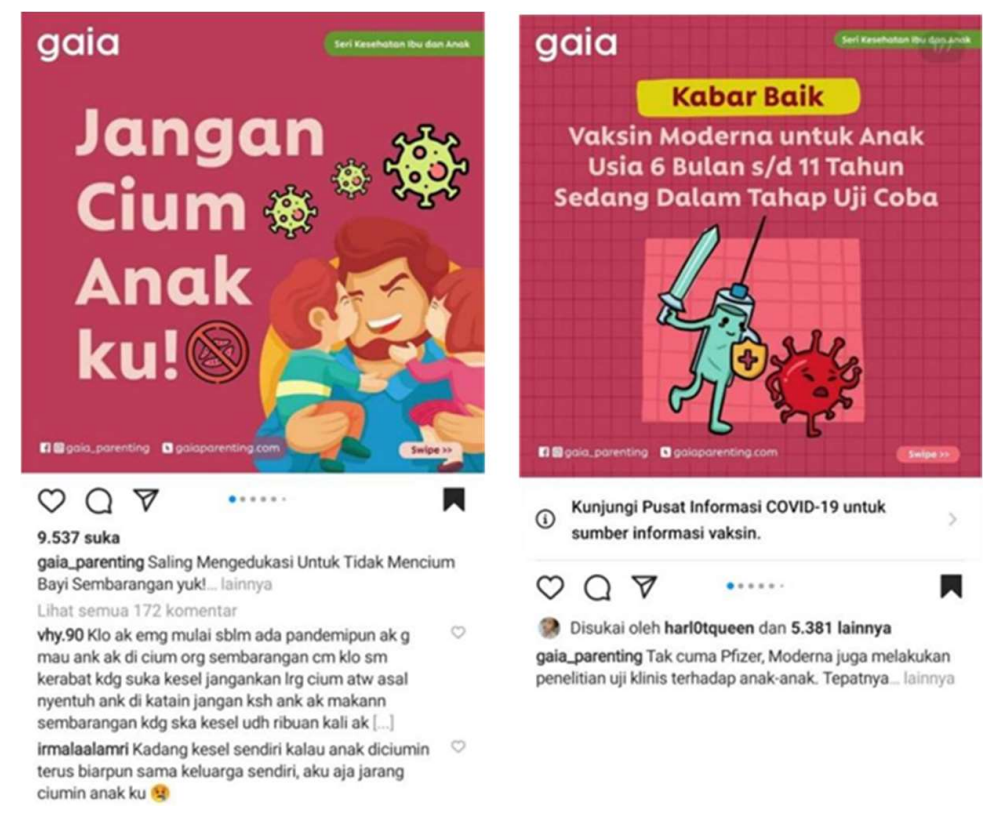

Gambar 8. Contoh postingan unsur strategi fungsi informatif. Sumber: Instagram Akun @gaia_parenting

Karakteristik dari postingan unsur strategi fungsi informasi adalah pertama, informasi yang disampaikan bersifat memberikan pengetahuan baru atau informasi umum yang bermanfaat terkait komunikasi risiko tentang kesehatan anak di masa pandemi Covid-19. Kedua, postingan mengenai informasi vaksin memiliki jumlah komentar tertinggi dan mengundang forum diskusi pada kolom komentar lebih banyak pada unsur strategi fungsi informasi dibandingkan postingan lainnya. Ketiga, penjelasan informasi dalam postingan dikemas dengan multiple slide information (lebih dari satu gambar) atau istilah lainnya adalah carousel. Jika tidak menggunakan carousel, maka penjelasan akan informasi terkait komunikasi risiko tentang kesehatan anak dijelaskan di dalam caption postingan.

Hasil penelitian ini mengungkapkan, bahwa berdasarkan lini masa pengunggahan delapan belas konten bahan kajian penelitian terkait unsur strategi fungsi informatif yang menunjukkan bahwa postingan dengan unsur fungsi informatif, cocok untuk diunggah ketika angka positif Covid-19 sedang terus meningkat yang membuat para orang tua haus akan informasi terkait komunikasi risiko tentang kesehatan anak.

Hasil kajian menunjukkan bahwa engagement yang tinggi dari postingan unsur strategi ini mengindikasikan bahwa postingan dengan unsur strategi ini memang dibutuhkan oleh para orang tua dalam upaya mencegah ataupun melakukan serangkaian perawatan terhadap anak yang terindikasi Covid-19. Indikator diterimanya jenis postingan dengan unsur ini dapat dilihat dari beberapa komentar di bawah ini. Berikut merupakan contoh diskusi dari para orang tua terkait dengan unsur strategi fungsi informatif.

"Wah ditunggu informasi selanjutnya :) Tahap preklinik dan tahap klinik dinyatakan aman untuk orang dewasa. Mudah-mudahan hasiknya baik untukanak-anak" (@aninditadewanti)

"Nah ini setuju banget, izin save yamin@gaia_parenting maubuat statuswabiar pada nyadar, udah disindir berkali2 tetap aja begitu,heranaku tuh," (@kecee_susii)

Edukatif. Unsur strategi fungsi edukatif merupakan unsur strategi yang menekankan informasi dalam mendorong terjadinya penambahan pengetahuan, perubahan sikap dan perilaku, serta keterampilan para khalayak. Dalam unsur strategi fungsi edukatif, masyarakat diharapkan mendapatkan berbagai informasi terkait komunikasi risiko tentang kesehatan anak yang dapat membantu proses pengambilan keputusan dan memilih tindakan yang tepat untuk menghadapi bahaya kesehatan yang mengancam anak. Hasil persentase dari analisis penelitian menunjukkan bahwa persentase postingan yang 
termasuk dalam kategori unsur strategi fungsi edukatif adalah sebesar $11.1 \%$ menjadikan strategi unsur ini sebagai jenis postingan terbanyak kedua setelah unsur fungsi informatif yang diaplikasikan oleh ketiga akun komunitas virtual. Alasannya adalah di masa pandemi Covid-19 ini para orang tua harus diberikan informasi yang mampu mendorong meningkatkan pemahaman terkait penyebaran virus Covid-19 sendiri yang berkaitan juga tujuannya agar terjadi perubahan sikap para orang tua dalam menghadapi masa pandemi ini, selain itu unsur fungsi edukatif juga berguna agar para orang tua dapat mengambil keputusan dalam bersikap yang tepat, seperti ketika menghadapi anak yang terinfeksi positif Covid-19 atau ketika orang tua, khususnya ibu sendiri yang terjangkit virus Covid-19 yang harus mencari cara untuk tetap dapat memberikan asi kepada anak. Dalam hasil kajian unit analisis, diketahui terdapat sepuluh postingan yang termasuk kategori unsur strategi fungsi edukatif, menjadikan informatif sebagai unsur fungsi terbanyak nomor dua setelah strategi unsur fungsi informatif. Berikut di bawah ini merupakan contoh postingan yang termasuk dalam kategori unsur strategi fungsi edukatif.
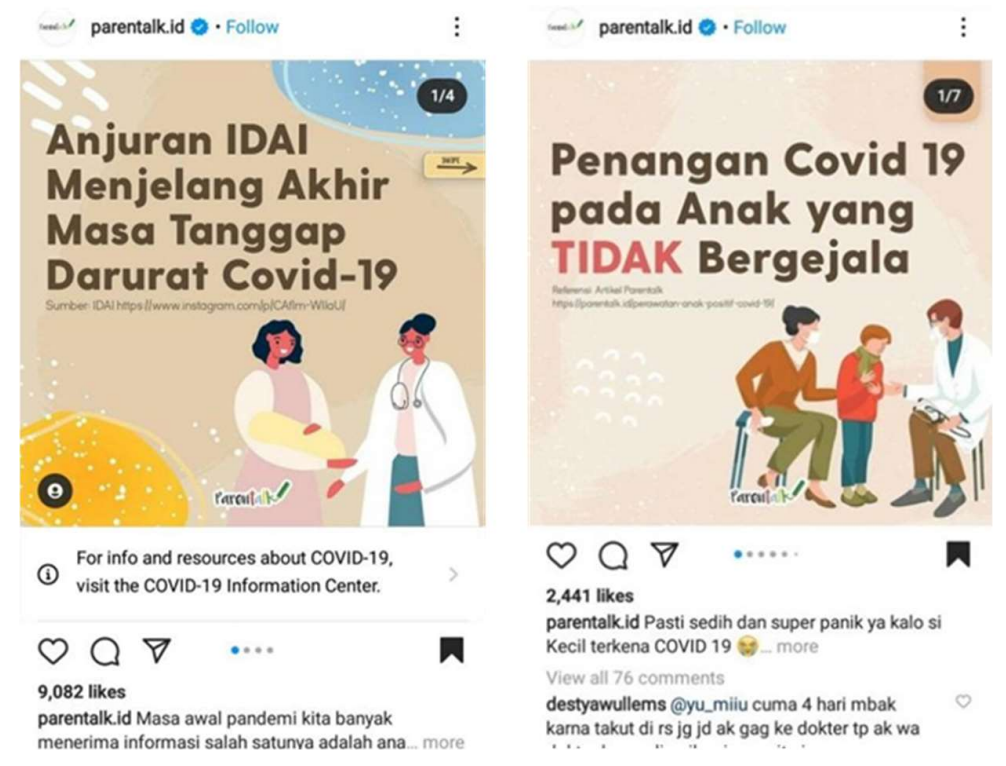

Gambar 9. Contoh postingan unsur strategi fungsi informatif. Sumber: Instagram Akun @ gaia_parenting

Hasil penelitian ini mengungkapkan, bahwa berdasarkan linimasa pengunggahan sembilan konten bahan kajian penelitian terkait unsur strategi fungsi edukatif, menunjukkan bahwa strategi unsur fungsi edukatif dibutuhkan dalam mendorong meningkatkan pemahaman orang tua dari awal Covid19 menyebar, ketika kasus Covid-19 meningkat, hingga saat memasuki masa new normal.

Hasil kajian menunjukkan engagement yang tinggi dari postingan unsur strategi ini menunjukkan bahwa postingan dengan unsur strategi ini memang dibutuhkan oleh para orang tua dalam mengedukasi memberikan pemahaman dan pengambilan keputusan, serta tindakan untuk melindungi anak dari paparan Covid-19 atau memberikan pedoman dalam menghadapi anak yang telah terinfeksi virus Covid-19. Indikator diterimanya jenis postingan dengan unsur ini dapat dilihat dari beberapa komentar di bawah berikut ini yang diambil dari kedua postingan di atas. Berikut merupakan contoh diskusi dari para orang tua terkait dengan unsur strategi fungsi edukatif.

"Thank you mimin sgt mengedukasi, ijin share ya" (@annemarieschool)

"Terimakasih sharingnya ya bumin, butuh banget artikel ini ;)" (@bukubalitadananakmurah)

Motivatif. Unsur strategi fungsi motivatif merupakan unsur strategi yang menekankan pada dorongan yang diberikan oleh akun komunitas virtual Instagram dengan tujuan untuk merangsang khalayak agar melakukan tindakan-tindakan atau sesuatu yang menjadi dasar dan alasan seseorang untuk berperilaku atau dalam melakukan sesuatu. Motivasi dibentuk dari elemen-elemen psikologis meliputi kepribadian, kemampuan, nilai-nilai, sikap dan suasana hati (Albab \& Saleh, 2013). Dalam hal ini, 
postingan yang dibuat oleh akun komunitas virtual adalah berupa re-post cerita-cerita motivasi terkait penanganan Covid-19 yang memiliki unsur komunikasi risiko tentang kesehatan anak untuk merangsang sikap dan suasana hari khalayak. Persentase dalam hasil kajian menunjukkan bahwa unsur strategi fungsi motivatif sebesar $2.2 \%$ membuat unsur strategi fungsi ini menempati urutan paling bawah jika dibandingkan dengan unsur strategi fungsi motivatif yang lainnya. Padahal, postingan dengan jenis unsur ini dapat menjangkau engagement yang tinggi jika dibandingkan postingan jenis lainnya. Hal ini disebabkan dalam postingan jenis unsur strategi edukatif memainkan peran afeksi khalayak yang sangat besar. Terlihat dari komentar dalam postingan tersebut, bahwa khalayak seolah turut merasakan apa yang sedang terjadi di dalam video tersebut. Postingan dengan unsur strategi ini dapat menjadi alternatif yang bagus dalam meningkatkan engagement akun komunitas virtual yang hendak membuat konten terkait komunikasi risiko pada anak. Terdapat dua postingan dalam unit analisis penelitian yang termasuk dalam kategori unsur strategi fungsi motivatif. Berikut di bawah ini merupakan contoh postingan yang tersebut.
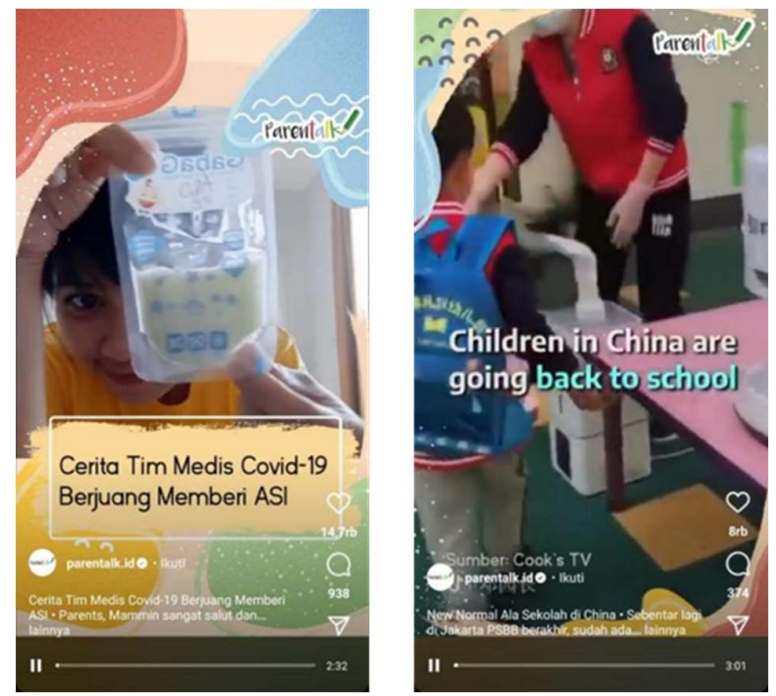

Gambar 10. Contoh postingan unsur strategi fungsi motivatif. Sumber: Instagram Akun @parentalk.id

Karakteristik dari postingan dengan unsur strategi fungsi motivatif ini adalah pertama, konten dalam postingan berusaha memainkan emosi, sehingga menyentuh afeksi khalayak untuk turut merasakan apa yang sedang terjadi di dalam video. Kedua, konten postingan berupa video akan lebih mudah mendapatkan engagement, karena perasaan emosi dapat tersampaikan dengan baik jika dibandingkan foto. Ketiga, konten video dapat berupa re-post dari sumber lainnya dengan tetap mencantumkan sumber aslinya. Keempat, konten unsur strategi fungsi motivatif dapat dengan mudah menarik perhatian khalayak dan cepat menyebarluas melalui algoritma Instagram, sehingga cocok digunakan untuk meningkatkan engagement. Kelima, dalam pengamatan peneliti melihat komentar terkait postingan motivatif, menunjukkan bahwa konten postingan jenis ini memungkinkan khalayak untuk turut berkomentar mengenai pengalaman serupa yang juga dialami oleh dirinya. Mengingat bahwa konten motivatif ini berisikan afeksi yang berusaha untuk memainkan emosi khalayak, maka pengunggahan di awal masa pademi adalah hal yang tepat, yakni masyarakat baru merasakan dan mencoba untuk melakukan transisi gaya hidup dari pola normal.

amee.yanwar Kok sedih ya lihatnya, smoga virus2 ini cepat hilang dr bumi ini ya Alloh, supaya anak2 dan jg para ortu tdk was $2 \mathrm{lg}$ melepas anak2nya ke sekolah atau keluar rumah, dan mreka pun di sekolah bisa happy (2)

$74 \mathrm{mg}$ Balas frisca_rizqi Dan aku ibu anak satu usianya 22 bulan, nangis liat videonya 2 merasakan jadi ibu+pejuang covid juga, semoga sehat selalu semuanya ${ }_{2}$ dan wabah ini segera berakhir, aamiin

$83 \mathrm{mg}$ Balas

Gambar 11. Komentar dalam postingan@parentalk.id. Sumber: Instagram Akun@parentalk.id 
Kedua postingan ini memiliki kesamaan, yakni berupa video dan berhasil mendapatkan engagement yang sangat tinggi dari segi like dan juga komentar jika dibandingkan postingan unsur strategi lainnya. Berikut merupakan komentar dari beberapa khalayak terkait dengan video motivatif tersebut. Gambar 11 (halaman sebelumnya) merupakan contoh diskusi dari para orang tua terkait dengan unsur strategi fungsi motivatif.

\section{Unsur Strategi Bentuk}

Foto atau Gambar. Foto atau gambar merupakan unsur strategi yang paling banyak digunakan oleh ketiga akun komunitas virtual dalam memproduksi konten terkait komunikasi risiko tentang kesehatan anak di Instagram. Persentase foto atau gambar dibandingkan bentuk lainnya adalah $25.5 \%$ menjadikan bentuk foto atau gambar sebagai bentuk yang paling utama dalam menyampaikan komunikasi risiko tentang kesehatan anak. Unsur strategi bentuk foto atau gambar memiliki dua jenis postingan, yakni foto tunggal (hanya terdapat satu foto dalam postingan) dan foto carousel (terdapat lebih dari dua foto dalam satu postingan). Namun perlu diperhatikan, bahwa foto atau gambar juga memiliki kekurangan, seperti hanya menampilkan persepsi indera mata dengan ukuran yang sangat terbatas (sulit untuk memasukkan semua informasi ke dalam foto atau gambar), memiliki kecenderungan diinterpretasikan secara personal dan subyektif (tergantung latar belakang dan budaya dari setiap khalayak), disajikan dalam ukuran yang kecil, 1080px x 1080px, 1920px x 1080px, dan $1080 \mathrm{px}$ x 1350px yang membuatnya harus diatur sedemikian rupa tata letaknya agar informasi yang ingin disampaikan dapat diterima dengan baik oleh khalayak. Apalagi mengingat bahwa informasi yang disampaikan tentang komunikasi risiko tentang kesehatan anak tidaklah sedikit. Jika jumlah slide dalam satu postingan terlalu banyak, juga akan cenderung membuat khalayak bosan dalam membacanya. Strategi yang dapat dilakukan untuk mengatasi hal tersebut adalah dengan cara membuat lebih dari satu postingan terkait dengan informasi yang ingin disampaikan.

Karakteristik dari unsur strategi bentuk foto atau gambar sebagai unsur strategi komunikasi risiko tentang kesehatan anak adalah pertama, bersifat jelas dan tidak menimbulkan makna ganda. Artinya gambar atau informasi yang terdapat di dalamnya harus jelas dan dapat membuat khalayak memahami dengan baik objek, peristiwa, ataupun informasi yang ingin disampaikan. Kedua, gambar harus sederhana, artinya komposisi dalam gambar harus diperhatikan dengan cukup jelas bagian-bagian yang penting agar mudah dipahami oleh khalayak. Ketiga, harus dipikirkan antara perpaduan keindahan dan kesesuaian gambar agar informasi penting yang ingin disampaikan tidak terhalangi oleh elemen-eleman lainnya yang membuat pesan tidak tersampaikan dengan baik. Keempat, memperhatikan komposisi gambar yang disediakan oleh Instagram. Umumnya konten terkait komunikasi risiko menggunakan komposisi gambar 1080px x 1080px.

Video. Video merupakan unsur strategi bentuk yang menempati urutan kedua dengan persentase yang sama dengan IGTV. Video merupakan fitur di Instagram yang digunakan oleh pengguna untuk memposting file audio visual pada feeds dengan durasi hanya 1 menit (60 detik). Biasanya video bisa diposting bersamaan dengan foto pada fitur multiple shares. Fitur lain Instagram untuk video adalah dapat mengkonversi langsung hasil fitur live di Instagram kedalam bentuk video di tampilan feeds, biasanya hasil konversi live ini dapat berdurasi hingga satu jam lebih. Hal ini merupakan kelebihan lain unsur bentuk video di Instagram karena setiap diskusi terkait komunikasi risiko yang dilakukan oleh komunitas virtual akun Instagram parenting dengan para ahli dapat secara otomatis tersimpan dan dapat ditonton kembali secara berulang. Video memiliki kelebihan daripada media lain karena mengkombinasikan audio dan visual dalam satu media (Nirwana et al., 2016).

Dari 30 unit analisis yang menjadi bahan kajian dalam penelitian, terdapat 3 unggahan yang menggunakan fitur video sebagai bentuk postingannya dengan persentase $3.3 \%$, jumlah yang sangat sedikit ketimbang unsur bentuk foto, kemungkinan besar dikarenakan jadwal target unggahan akun Instagram parenting yang padat, sehingga sedikit sulit jika membuat sebuah video. Tetapi sebenarnya melakukan diskusi di live terkait komunikasi risiko tentang kesehatan anak di masa pandemi Covid-19 sebenarnya sangat bisa untuk diterapkan. Kelebihan dalam bentuk ini adalah dapat mengunggah video bersamaan dengan bentuk foto, serta mampu secara otomatis mengkonversi hasil live Instagram menjadi video pada tampilan feeds. Adapun kekurangan dari fitur ini adalah batas waktu yang telalu sedikit untuk mengunggah video, serta penggunaan kuota yang cukup besar ketika melihat video hasil diskusi live streaming yang memakan waktu hingga satu jam. Kemudian kekurangan lainnya terletak pada jaringan juga berpengaruh besar terhadap kualitas resolusi video yang diputarkan. Diperlukan jaringan yang bagus agar para khalayak dapat menikmati pengalaman membuka informasi terkait 
komunikasi risiko tentang kesehatan anak secara maksimal, jika tidak maka informasi akan sulit untuk tersampaikan dengan baik kepada khalayak.

IGTV. IGTV merupakan unsur strategi bentuk yang menempati urutan ketiga dengan persentase yang sama dengan video. IGTV merupakan fitur dari Instagram yang memungkinkan khalayak untuk mengunggah video dengan durasi yang jauh lebih panjang jika dibandingkan video biasa. Di fitur posting biasa, video pada Instagram hanya bisa diunggah dengan durasi terbatas, yakni satu menit saja. Melalui IGTV, memungkinkan akun komunitas virtual dapat mengunggah video sekitar 1-15 menit. Mengingat bahwa pesan yang disampaikan dalam komunikasi risiko biasanya tidak sedikit, maka penggunaan fitur IGTV menjadi penting bagi pengelolaan komunikasi risiko tentang kesehatan anak oleh komunitas virtual. Selain itu, perbedaan lainnya adalah komposisi video pada IGTV tidak berbentuk kotak 1080px x 1080px layaknya video biasa, melainkan fullscreen potrait berukuran $1080 \mathrm{px}$ x 1920px. Walaupun demikian, fitur dalam IGTV juga sebenarnya memungkinkan penggunanya untuk mengunggah konten landscape, namun hal ini sangat jarang diterapkan, karena karakteristik utama dari IGTV itu sendiri adalah potrait. Dari 30 unit analisis yang menjadi bahan kajian dalam penelitian, terdapat 3 unggahan yang menggunakan fitur IGTV sebagai bentuk postingannya dengan persentase $3.3 \%$, jumlah yang sedikit mengingat sebenarnya IGTV merupakan pilihan bentuk yang sangat tepat dalam menyampaikan informasi penting terkait komunikasi risiko tentang kesehatan anak yang membutuhkan platform dengan durasi waktu yang panjang.

Karakteristik dari bentuk IGTV sebagai unsur strategi dalam komunikasi risiko tentang kesehatan anak adalah pertama, video yang ditampilkan biasanya merupakan pesan disampaikan oleh pakar atau orang yang ahli dibidangnya, misalnya dokter, psikolog, pakar anak, dan sebagainya. Kedua, penggunaan komposisi IGTV lebih condong ke potrait. Ketiga, IGTV cocok digunakan untuk menyampaikan pesan strategi komunikasi anak dalam jumlah informasi yang banyak, karena durasi yang disediakan cukup panjang yakni maksimal 15 menit. Keempat, penting untuk memperhatikan durasi dalam video tidak terlalu panjang agar tidak membosankan para penonton. Oliver Foo, VP Business Development \& COE Programme Singtel International Group, menyarankan bahwa durasi 3-5 menit adalah waktu ideal bagi para penonton ketika mengkonsumsi video pada media sosial (Rachmatunnisa, 2016).

Reels. Reels merupakan fitur terbaru di Instagram yang fungsi kerjanya mirip dengan aplikasi TikTok. Reels pertama kali muncul pada 23 Juni, 2021. Pada awalnya reels hanya memiliki durasi 15 detik seperti story Instagram tetapi pada bulan Agustus, durasi reels di perpanjang hingga 1 menit (60 detik). Dari 30 analisis hanya terdapat 1 postingan yang menggunakan reels dari akun @gaia_parenting, hal ini membuat unsur bentuk reels berada di frekuensi terakhir sebanyak 1.1\%. Frekuensi rendah juga dipengaruhi dari faktor kebaruan fitur reels di Instagram, sehingga masih jarang digunakan oleh akun Instagram parenting.

Produksi konten dengan mengemas dalam bentuk reels adalah efektif untuk dilakukan karena lebih banyak mendapatkan engagement dari publik, hal ini juga didukung kemudahan untuk melihat reels seperti pada aplikasi TikTok, yaitu hanya cukup menggeser (slide) ke atas atau kebawah. Karakteristik postingan dalam unsur bentuk reels, yaitu variasi dalam mengedit video dengan beberapa fitur menarik, seperti bisa menambahkan backsong pada video, mengatur jumlah durasi yang diingankan mulai dari, 15, 30, dan 60 detik, dilengkapi dengan fitur Instagram filter, dan video layout untuk menggabungkan dua video sekaligus. Dalam komunikasi risiko sendiri bentuk unggahan reels dari @gaia_parenting telah menerapkan durasi 60 detik, fitur backsong, dan tulisan penjelasan yang sangat bermanfaat.

\section{KESIMPULAN}

Secara umum hasil penelitian ini menghasilkan temuan bahwa pada dasarnya minat khalayak terhadap konten terkait komunikasi risiko tentang kesehatan anak sangatlah tinggi, yakni didasarkan pada besarnya engagement yang dilihat dari jumlah like yang banyak dan partisipasi komentar para orang tua yang aktif terhadap hampir setiap konten komunikasi tentang risiko kesehatan anak yang menjadi unit analisis kajian penelitian. Hal ini dikarenakan para orang tua menyadari bahwa konten komunikasi risiko tentang kesehatan anak penting dalam meningkatkan pemahaman, kesadaran, dan perhatian, kemudian memberikan panduan langkah demi langkah bagaimana suatu penanganan sehingga dapat melakukan pengambilan keputusan dalam upaya pencegahan dan perawatan anak di masa pandemi Covid-19. Namun, peneliti menemukan fakta di lapangan bahwa ternyata produksi konten komunikasi risiko tentang kesehatan anak masih sangat sedikit dilakukan oleh komunitas virtual yang memiliki fokus produksi konten terkait pola asuh (parenting) di Indonesia, yakni 
dibuktikan dari 4136 postingan periode Maret 2020 - September 2021 hanya terdapat 30 postingan $(0.72 \%)$ yang memuat pesan tentang komunikasi risiko tentang kesehatan anak. Akibatnya publikasi informasi terkait komunikasi risiko tentang kesehatan anak tidak tersalurkan secara maksimal, artinya tidak semua orang tua terutama yang memiliki anak mendapatkan informasi penting terkait komunikasi risiko tentang kesehatan anak. Padahal di masa pandemi Covid-19, informasi tersebut menjadi urgensi sangat penting karena menyangkut keselamatan anak.

Beberapa temuan dalam penelitian ini adalah pertama, terdapat hubungan antara dampak pandemi Covid-19 terhadap hadirnya konten komunikasi risiko tentang kesehatan anak yang menjadi konsentrasi tersendiri bagi masyarakat, khususnya para orang tua yang khawatir akan kondisi anaknya di masa pandemi. Hal ini diapliaksikan melalui adanya ungguhan khusus segmentasi komunikasi risiko tentang kesehatan anak yang memiliki target khalayak spesifik, yakni para orang tua. Kedua, hasil kajian analisis penelitian ini mengungkapkan bahwa dari segi unsur strategi tema, upaya preventif melindungi anak dari paparan virus Covid-19 merupakan bahan diskusi yang paling banyak dijadikan konten oleh ketiga akun komunitas virtual parenting. Hal ini ditandai dengan total unggahan postingan dengan tema upaya preventif melindungi anak dari paparan virus Covid-19 adalah 13 dari 30 postingan. Ketiga, unsur infomatif merupakan strategi fungsi yang paling banyak dibuat menjadi konten oleh komunitas virtual parenting. Hal ini ditandai dengan jumlah postingan yang menerapkan unsur strategi informatif adalah 19 dari 30 postingan. Keempat, bentuk foto merupakan unsur strategi bentuk yang paling banyak digunakan jika dibandingkan dengan bentuk lainnya, yakni 23 dari 30 postingan menggunakan foto sebagai bentuk pengemasan informasi terkait komunikasi risiko tentang kesehatan anak. Kelima, peneliti melihat bahwa terdapat potensi yang besar pada penggunaan Reels, sebagai fitur untuk mengemas pesan komunikasi risiko tentang kesehatan anak. Hal ini didasarkan pada sebuah postingan dari salah satu komunitas virtual parenting yang menerapkan penggunaan fitur Reels dan berhasil mendapatkan engagement yang tinggi.

\section{DAFTAR PUSTAKA}

Abrams, E. M., \& Greenhawt, M. (2020). Risk communication during COVID-19. The Journal of Allergy and Clinical Immunology: In Practice, 8(6), 1791-1794. DOI: 10.1016/j.jap.2020.04.012.

Albab, Marwan., Amiruddin Saleh. (2013). Hubungan Motivasi dan Pola Menonton dengan Tingkat Kepuasan Pemirsa pada Program Berita Topik ANTV (Kasus Pemirsa di Komplek Perumahan Pondok Sukatani Permai, Tapos, Kota Depok). Jurnal Komunikasi Pembangunan. DOI: https://doi.org/10.46937/1120139069

Adriani M, Bambang W (2014). Gizi dan Kesehatan Balita (Peranan Mikro Zinc pada pertumbuhan balita). Jakarta : Kencana

Anonymus. 2020. Komunikasi Risiko: Upaya Kemenkes Distribusikan Informasi Selama Pandemi. Diakses pada 07 Januari 2022 melalui laman https://humasindonesia.id/berita/komunikasi-risikoupaya-kemenkes-distribusikan-informasi-selama-pandemi-321

Beck, Ulrich. (2009).World at Risk. Malden: Polity Press. ISBN-13: 978-0-7456-4200-0

Covi, Michelle P., \&Donna, Jean K. (2016) "Sea-Level Rise Risk Communication: Public Understanding, Risk Perception, and Attitudes about Information." Environmental Communication 10 (5) : 612-633. https://doi.org/10.1080/17524032.2015.1056541.

Dabbagh, Z. 2020. The Role of Decision-maker in Crisis Management: A qualitative Study Using Grounded Theory (COVID-19 Pandemic Crisis as A Model). Journal of Public Affairs 20 (4). DOI: https://doi.org/10.1002/pa.2186

Damayanti, A. (2020). Instagram sebagai Medium Komunikasi Risiko di Masa Pandemi COVID-19: Studi Netnografi terhadap Komunitas Online KawalCOVID19. id. Jurnal Komunikasi Pembangunan. DOI: https://doi.org/10.46937/18202032355

Dharmawan, Heribertus C. B. (2020) Strategi komunikasi pengurangan risiko bencana oleh BNPB melalui Instagram @bnpb_indonesia. Masters thesis, Universitas Pelita Harapan. http://repository.uph.edu/10539/

Grid. (2018). Sudahkah Konten Video Anda Optimal?. Diakses pada 04 November 2021 melalui laman https://grid.co.id/index.php/blog/Sudahkah-Konten-Video-Anda-Optimal 
Hasanah, R. (2021). Analisis Konten Komunikasi Risiko Di Akun Instagram Gubernur Provinsi Sumatera Utara Selama Pandemi Covid-19.Retrieved from http://eprints.ums.ac.id/id/eprint/91840.

Kantar. 2020. Covid19 Impact on Indonesian Attitudes and Behavior: Learning from Brands

Kaplan, A. M., \& Haenlein, M. (2010). Users of the world, unite! The challenges and opportunities of Social Media. Business Horizons, 53(1), 59-68. DOI:10.1016/j.bushor.2009.09.003

KhalilM., SalehA., \& GintingB. (2018). Pemanfaatan Internet sebagai Media Komunikasi oleh Pengelola Sekretariat Dewan Ketahanan Pangan Provinsi. Jurnal Komunikasi Pembangunan, 15(2). https://doi.org/10.46937/15201722800

Kozinet, \& Gambetti. (2021). Netnography Unlimited: Understanding Technoculture Using Qualitative Social Media Research. New York: Routledge. ISBN 9781003001430

Kozinet, R. (2015). Netnography: Redefined. London: Sage Publication.ISBN 9781446285756.

Moleong, L.J. (2011). Metodologi Penelitian Kualitatif Edisi Revisi. Bandung: PT. Remaja Rosdakarya. ISBN: 979-514-051-5

Napoleon, Cat. (2020). Instagram users in Indonesia. Diakses pada 08 Januari 2022 melalui laman https:/napoleoncat.com/stats/instagram-users-in-indonesia/2021/01/

Ndlela, Martin N. (2019). "A Stakeholder Approach to Risk Management." In Crisis Communication: A Stakeholder Approach. Palgrave Pivot, Cham.p.53-75. ISBN 978-3-319-97255-8. DOI: https://doi.org/10.1007/978-3-319-97256-5_4

NirwanaT. P., SalehA., \& MatindasK. (2016). Pengaruh Penyajian Visual Dan Gaya Bahasa Pada Video Tentang Pariwisata Di Kabupaten Garut Terhadap Peningkatan Pengetahuan. Jurnal Komunikasi Pembangunan, 14(2). https://doi.org/10.46937/14201613766

Patrianti, T., Shabana, A., \& Tuti, R. W. (2020). Komunikasi Risiko Pemerintah Pada Penurunan Emisi Gas Rumah Kaca Untuk Mengatasi Perubahan Iklim Government Risk Communication On Greenhouse Gas Emission Reduction To Tackle Climate Change. Jurnal Penelitian Komunikasi Dan Opini Publik, 24(2), 156-170.

Rachmatunnisa. (2016). Berapa Lama Pengguna Insternet Betah Menonton Video?. Diakses pada 06 November 2021 melalui laman https:/inet.detik.com/cyberlife/d-3351168/berapa-lamapengguna-internet-betah-nonton-video

Shaw, Rajib. dkk. (2013). Risk Communication. World Bank, Washington, DC. (C) World Bank. https://openknowledge.worldbank.org/handle/10986/16147 License: CC BY 3.0 IGO

Suri, D. (2019). Pemanfaatan Media Komunikasi dan Informasi dalam Perwujudan Pembangunan $\begin{array}{llll}\text { Nasional. Jurnal Komunikasi } & \text { Pembangunan, } & \text { 17(2), } & \text { 177-187. }\end{array}$ https://doi.org/10.46937/17201926848

Sri Devi Octavia Surbakti, \& Indra Budi Laksana. (2021). Strategi Komunikasi Risiko Kementerian Kesehatan Republik Indonesia Dalam Upaya Penanggulangan Covid-19 Melalui Media Sosial. Sosioedukasi : Jurnal Ilmiah Ilmu Pendidikan Dan Sosial, 10(2), 217-1228. https://doi.org/10.36526/sosioedukasi.v10i2.1542

Turner, Lynn. (2008). Pengantar Teori Komunikasi. Jakarta: Salemba Humanika. ISBN 978-97917492-2-0. Halaman 55.

World Health Organization. (2020). Risk Communication and Community Engagement (RCCE) Readiness and Response to The 2019 Novel Coronavirus (2019-nCoV) (Interim guidance v2. No. $W H O / 2019-n C o V / R C C E / v 2020.2)$. World Health Organization. https://www.who.int/p ublications/i/item/risk-communication-andcommunity-engagement-readiness-and-initialresponse-for-novel-coronaviruses 